\title{
A Transparent window into biology: $A$ primer on Caenorhabditis elegans
}

\author{
Ann K. Corsi ${ }^{1}$, Bruce Wightman ${ }^{2 \S}$, and Martin Chalfie ${ }^{3 \S}$ \\ ${ }^{1}$ Biology Department, The Catholic University of America, Washington, DC 20064 \\ ${ }^{2}$ Biology Department, Muhlenberg College, Allentown, PA 18104 \\ ${ }^{3}$ Department of Biological Sciences, Columbia University, New York, NY 10027
}

\section{Table of Contents}

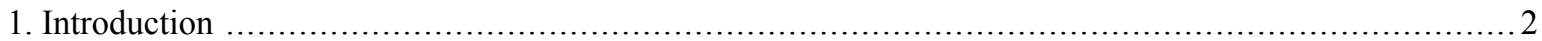

2. C. elegans basics ..................................................................................... 4

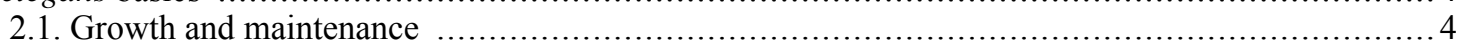

2.2. Sexual forms and their importance .............................................................. 5

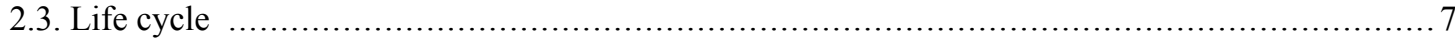

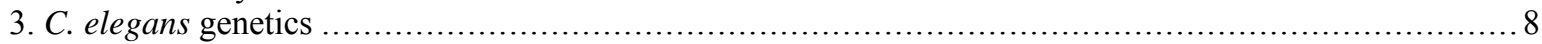

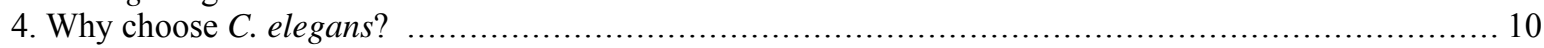

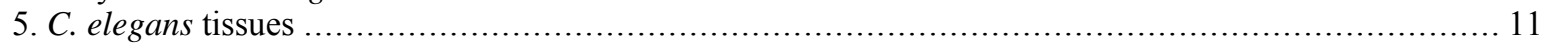

5.1. Epidermis: a model for extracellular matrix production, wound healing, and cell fusion .......... 12

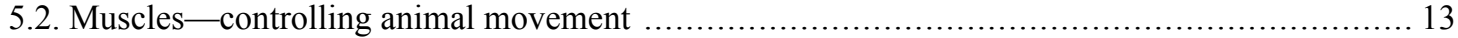

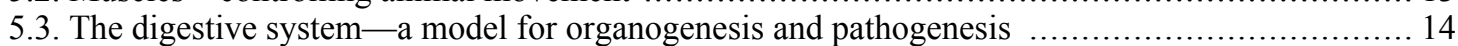

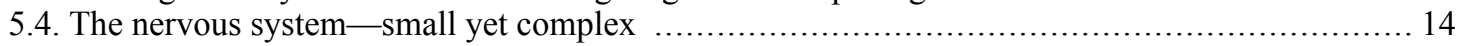

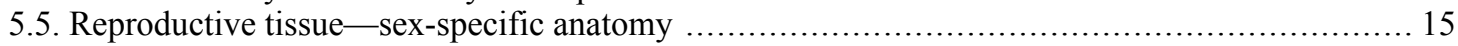

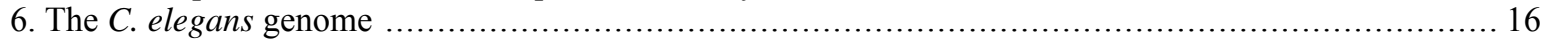

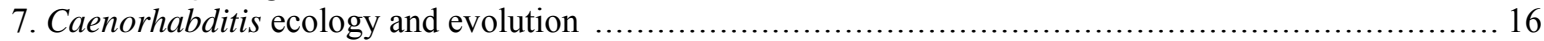

8. Brief history of $C$. elegans research and key discoveries ............................................. 17

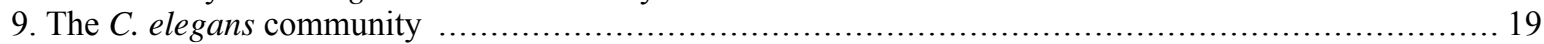

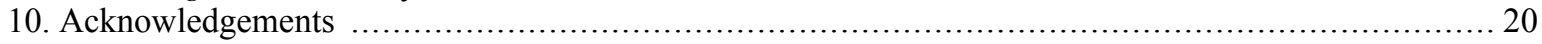

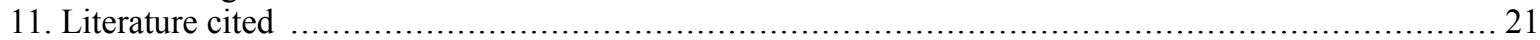

Here for the first time, WormBook and GENETICS co-publish an article. We wish to thank Tracey DePellegrin, Ruth Isaacson, and Elizabeth De Stasio of GENETICS for their dedication to this collaboration, as well as Editor-in-Chief Mark Johnston for his support of the project.

\footnotetext{
${ }^{*}$ Edited by E. A. De Stasio. Published June 18, 2015. This chapter should be cited as: Corsi A.K., Wightman B., and Chalfie M. A Transparent window into biology: A primer on Caenorhabditis elegans (June 18, 2015), WormBook, ed. The C. elegans Research Community, WormBook, doi/10.1895/wormbook.1.177.1, http://www.wormbook.org.

Copyright: ( 12015 Ann K. Corsi, Bruce Wightman, and Martin Chalfie. This is an open-access article distributed under the terms of the Creative Commons Attribution License, which permits unrestricted use, distribution, and reproduction in any medium, provided the original author and source are credited.

${ }^{\S}$ To whom correspondence should be addressed. E-mail: corsi@cua.edu, wightman@muhlenberg.edu, or mc21@columbia.edu.
} 


\section{Summary}

A little over 50 years ago, Sydney Brenner had the foresight to develop the nematode (round worm) Caenorhabditis elegans as a genetic model for understanding questions of developmental biology and neurobiology. Over time, research on $C$. elegans has expanded to explore a wealth of diverse areas in modern biology including studies of the basic functions and interactions of eukaryotic cells, host-parasite interactions, and evolution. C. elegans has also become an important organism in which to study processes that go awry in human diseases. This primer introduces the organism and the many features that make it an outstanding experimental system, including its small size, rapid life cycle, transparency, and well-annotated genome. We survey the basic anatomical features, common technical approaches, and important discoveries in C. elegans research. Key to studying $C$. elegans has been the ability to address biological problems genetically, using both forward and reverse genetics, both at the level of the entire organism and at the level of the single, identified cell. These possibilities make $C$. elegans useful not only in research laboratories, but also in the classroom where it can be used to excite students who actually can see what is happening inside live cells and tissues.

Keywords C. elegans; nematodes; Primer; single-cell analysis; transparent genetic system

\section{Introduction}

In 1963, Sydney Brenner sent a letter to Max Perutz, the chairman of the Medical Research Council's Laboratory of Molecular Biology (LMB), detailing his concerns that the "classical problems of molecular biology have either been solved or will be solved in the next decade" and proposing that the future of molecular biology lies in the extension to other fields, "notably development and the nervous system" (Brenner 1988; Brenner 2002). With the simplicity and power of prokaryotic genetics in mind, he proposed that a nematode (round worm), Caenorhabditis briggsae, would be an ideal system in which to tackle these problems. Later, he settled on the related nematode C. elegans as the focus of his efforts because the elegans strain grew better than the briggsae isolate in Brenner's laboratory (Félix 2008). Today, C. elegans is actively studied in over a thousand laboratories worldwide (www.wormbase.org) with over 1200 C. elegans research articles published each year for the last 5 years.

Caenorhabditis elegans is a tiny, free-living nematode found worldwide. Newly hatched larvae are 0.25 millimeters long and adults are 1 millimeter long. Their small size means that the animals are usually observed with either dissecting microscopes, which generally allow up to $100 \mathrm{X}$ magnification, or compound microscopes, which allow up to $1000 \mathrm{X}$ magnification. The dissecting microscope is used to observe worms on Petri dishes (Figure 1, A and B) as they move, eat, develop, mate, and lay eggs (for movies showing these features, see http://labs.bio.unc.edu/Goldstein/movies.html). A compound or confocal microscope allows observation at much finer resolution (Figure 1C), permitting researchers to perform experiments that address questions related to cell development and function at single-cell resolution. Because $C$. elegans is transparent, individual cells and subcellular details are easily visualized using Nomarski (differential interference contrast, DIC) optics (Figure 1C). Enhanced detail can be discerned by using fluorescent proteins to tag proteins or subcellular compartments (Figure 1D). Fluorescent proteins can also be used to study developmental processes, screen for mutants affecting cell development and function, isolate cells, and characterize protein interactions in vivo (Chalfie et al. 1994; Boulin et al. 2006; Feinberg et al. 2008). 

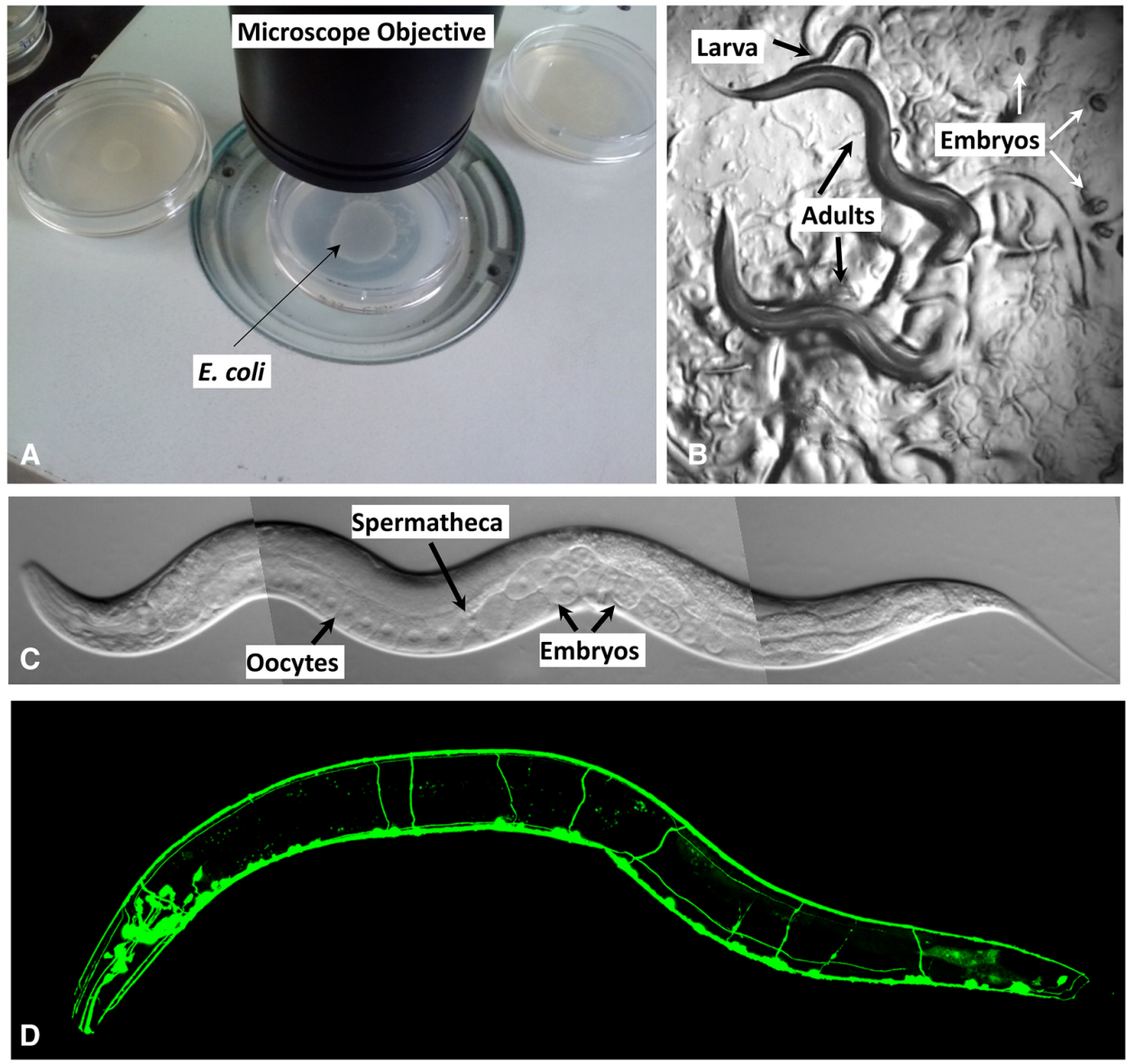

Figure 1. Observing C. elegans. (A) Petri dishes sitting on the base of a dissecting stereomicroscope. Bacterial lawns are visible on the surface of the agar inside the dishes but the $C$. elegans are too small to be seen in this view. (B) C. elegans viewed through the dissecting microscope. The two adults are moving in this view. Tracks in the plate indicate where animals have traveled on the bacterial lawn. (C) An adult hermaphrodite is viewed in a compound microscope. In all pictures, anterior is to the left and ventral is on the bottom. C. elegans moves on either its left or right side; in this image the surface facing the viewer is the left side. Because the animals are transparent, one can see, from left to right on the ventral side, developing oocytes in the gonad (rectangular cells with a clear, circular nucleus inside) followed by the spermatheca (where oocytes are fertilized), and multiple embryos in the uterus. (D) Fluorescent image showing the nervous system labeled with a GFP reporter (sto-6::gfp). Photo credits: (C) Original (modified here): B. Goldstein; (D) J. Kratz.

C. elegans has a rapid life cycle ( 3 days at $25^{\circ}$ from egg to egg-laying adult) and exists primarily as a self-fertilizing hermaphrodite, although males arise at a frequency of $<0.2 \%$ (Figure 2). These features have helped to make C. elegans a powerful model of choice for eukaryotic genetic studies. In addition, because the animal has an invariant number of somatic cells, researchers have been able to track the fate of every cell between fertilization and adulthood in live animals and to generate a complete cell lineage (Sulston and Horvitz 1977; Kimble and Hirsh 1979; Sulston et al. 1983). Researchers have also reconstructed the shape of all C. elegans cells from electron micrographs, including each of the 302 neurons of the adult hermaphrodite (White et al. 1986) and the posterior mating circuit in the adult male (Jarrell et al. 2012). These reconstructions have provided the most complete "wiring diagrams" of any nervous system and have helped to explain how sexual dimorphism affects neuronal circuits. Moreover, because of the invariant wild-type cell lineage and neuroanatomy of $C$. elegans, mutations that give rise to developmental and behavioral defects are readily identified in genetic screens. Finally, because C. elegans was the first multicellular organism with a complete genome sequence (C. elegans Sequencing Consortium 1998), forward and reverse genetics have led to the molecular identification of many key genes in developmental and cell biological processes. 


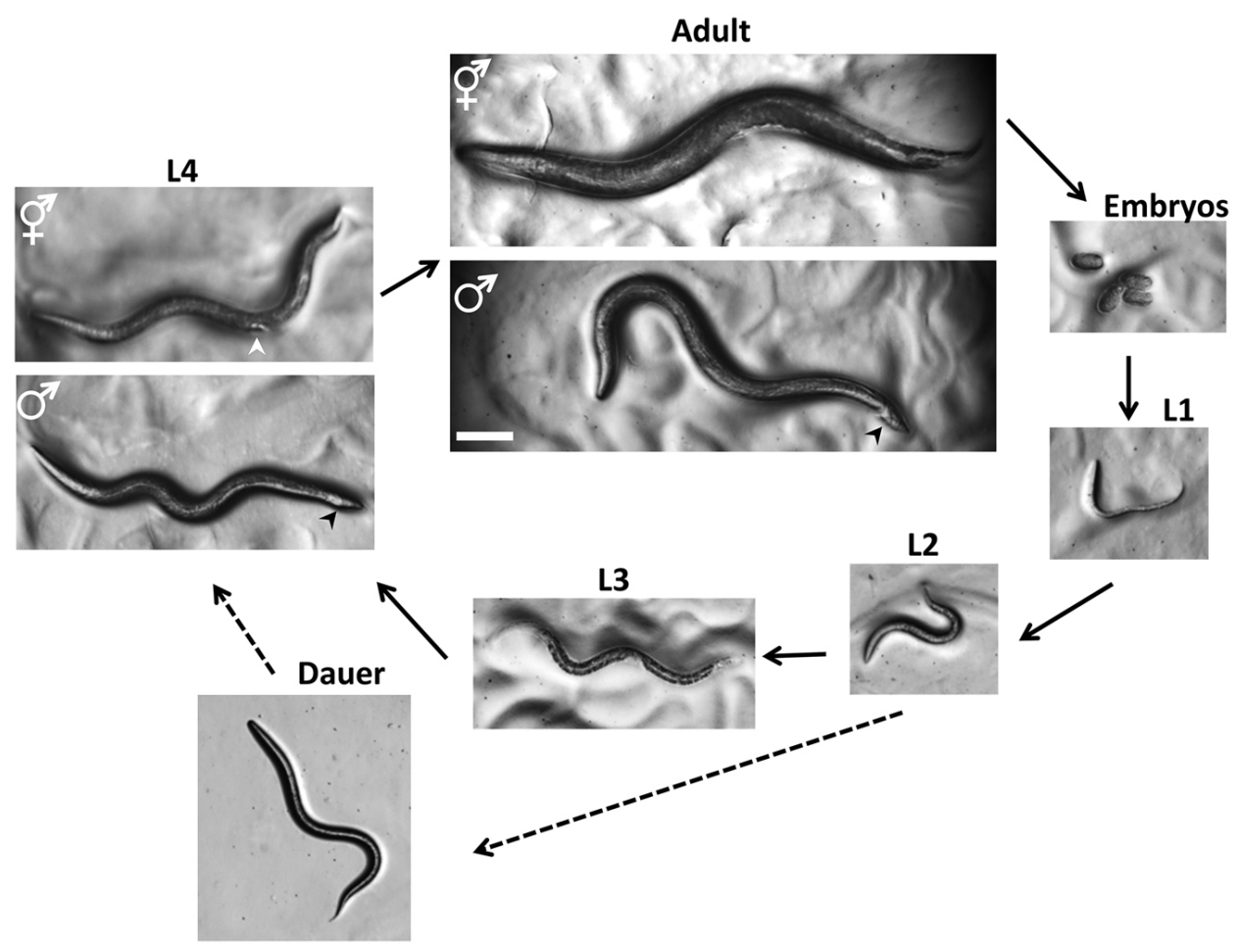

Figure 2. Life Cycle of C. elegans. Animals increase in size throughout the four larval stages, but individual sexes are not easily distinguished until the L4 stage. At the L4 stage, hermaphrodites have a tapered tail and the developing vulva (white arrowhead) can be seen as a clear half circle in the center of the ventral side. The males have a wider tail (black arrowhead) but no discernable fan at this stage. In adults, the two sexes can be distinguished by the wider girth and tapered tail of the hermaphrodite and slimmer girth and fan-shaped tail (black arrowhead) of the male. Oocytes can be fertilized by sperm from the hermaphrodite or sperm obtained from males through mating. The dauer larvae are skinnier than all of the other larval stages. Photographs were taken on Petri dishes (note the bacterial lawns in all but the dauer images). Bar $0.1 \mathrm{~mm}$.

The experimental strengths and the similarities between the cellular and molecular processes present in $C$. elegans and other animals across evolutionary time (metabolism, organelle structure and function, gene regulation, protein biology, etc.) have made C. elegans an excellent organism with which to study general metazoan biology. At least $38 \%$ of the C. elegans protein-coding genes have predicted orthologs in the human genome (Shaye and Greenwald 2011), 60-80\% of human genes have an ortholog in the C. elegans genome (Kaletta and Hengartner, 2006), and $40 \%$ of genes known to be associated with human diseases have clear orthologs in the C. elegans genome (Culetto and Satelle 2000). Thus, many discoveries in C. elegans have relevance to the study of human health and disease.

\section{C. elegans basics}

\subsection{Growth and maintenance}

C. elegans, although often mischaracterized as a soil nematode, can most easily be isolated from rotting vegetable matter, which contains an ample supply of their bacterial food source (Barrière and Félix 2014). In the laboratory, animals are normally grown on agar plates containing a lawn of the bacterium Escherichia coli. Once the animals deplete the bacteria, they utilize their fat supply. Without food, the development of young larval stage animals is arrested. As a result of entering this stasis, animals can survive for at least a month (often starved plates can be usefully kept for up to six months at $15^{\circ}$ ), and as stocks, they do not require constant feeding. Whenever healthy, growing animals are needed, a piece of the agar from the old plate can be transferred to a new plate with bacteria. The animals move to the new bacteria and resume their development.

Several other features greatly facilitate the maintenance of $C$. elegans stocks and their experimental use. First, because $C$. elegans is a self-fertilizing hermaphrodite (see the following section), a single animal can populate a plate. Second, animal populations can be frozen for years and revived when needed. Third, the animal's small size means that many can be grown in a small space. Fourth, animals can be grown at temperatures ranging from $12^{\circ}$ to $25^{\circ}$; their $\mathrm{Q}_{10}$ for growth is $\sim 2$ (that is, an increase of $10^{\circ}$ speeds up growth twofold). Growth at different 
temperatures makes it possible to control the rate of animal development and assists in the isolation and use of temperature-sensitive mutants. Continual growth above $25^{\circ}$ is not possible because the animals become sterile. The upper temperature limit can be a problem if animals are kept on bench tops (instead of temperature-controlled incubators) in rooms that are too warm. Shorter exposures to higher temperatures are possible for heat shock experiments and to increase production of males (Sulston and Hodgkin 1998). Fifth, animals can be synchronized by isolating newly hatched larvae or by treating gravid adults with bleach (which decontaminates by killing everything but embryos) and isolating eggs, which are resistant to bleach treatment. Sixth, to facilitate biochemical studies animals can be grown in bulk in liquid medium. "Worm sorters" such as the COPAS Biosorter are also available to quickly select large quantities of individual worms with desired characteristics. Finally, one does not need especially expensive equipment beyond a good dissecting microscope and a compound microscope to work with this animal. Overall, the animals are inexpensive and convenient to maintain.

\subsection{Sexual forms and their importance}

Wild-type C. elegans has two sexual forms: self-fertilizing hermaphrodites and males (Figure 2 and Figure 3 , $\mathrm{A}$ and B). The gonad of hermaphrodites forms an ovotestis that first produces haploid amoeboid sperm that are stored in the spermatheca in the L4 stage and then near adulthood the germ line switches fate to produce much larger oocytes. Essentially hermaphrodites are females whose gonads temporarily produce sperm before they produce oocytes. Hermaphrodites can produce up to 300 self-progeny that are fertilized by the stored sperm. If mated with males, hermaphrodites are capable of producing 1000 offspring, indicating that hermaphrodite-produced sperm is a limiting factor in self-fertilization. Both sexes are diploid for the five autosomal chromosomes. The sexes differ in that hermaphrodites have two $\mathrm{X}$ chromosomes and males have a single $\mathrm{X}$ chromosome-C. elegans has no $\mathrm{Y}$ chromosome - and the genotype of males is referred to as XO. Sex is determined by the X to autosome (X:A) ratio (Zarkower 2006). The majority of offspring produced by self-fertilization are hermaphrodites; only $0.1-0.2 \%$ of the progeny are males due to rare meiotic non-disjunction of the $\mathrm{X}$ chromosome. Because hermaphrodites make their own sperm, in genetic crosses self-progeny (oocytes fertilized by the hermaphrodite's sperm) need to be distinguished from cross-progeny. For example, when hermaphrodites homozygous for a recessive mutation causing a visible mutant phenotype are mated to wild-type males, the self-progeny hermaphrodites show the mutant phenotype and the cross-progeny hermaphrodites do not.

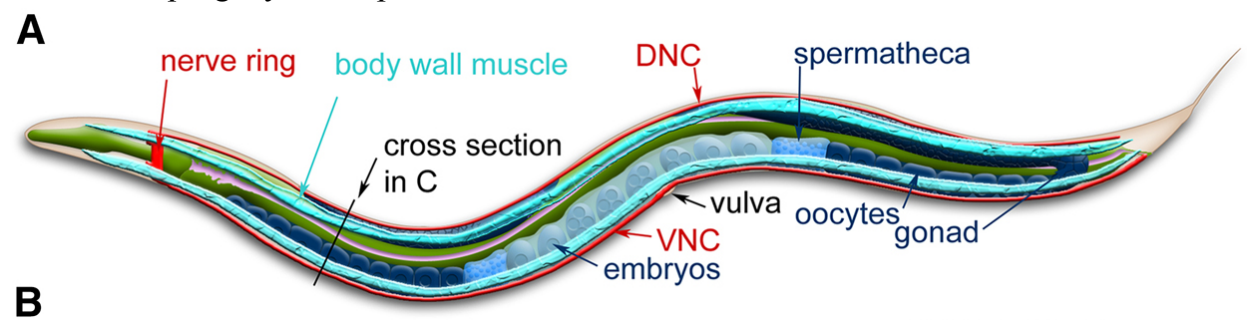

B

tail fan with rays
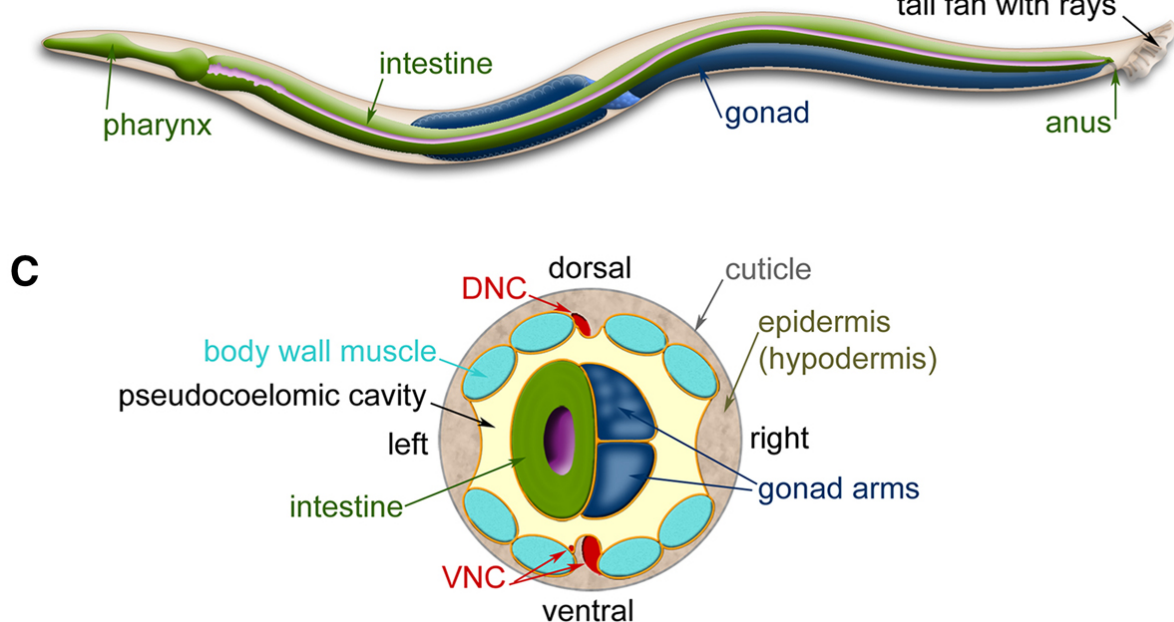

Figure 3. C. elegans anatomy. Major anatomical features of a hermaphrodite (A) and male (B) viewed laterally. (A) The dorsal nerve cord (DNC) and ventral nerve cord (VNC) run along the entire length of the animal from the nerve ring. Two of the four quadrants of body wall muscles are shown. (B) The nervous system and muscles are omitted in this view, more clearly revealing the pharynx and intestine. (C) Cross-section through the anterior region of the C. elegans hermaphrodite (location marked with a black line in A) showing the four muscle quadrants surrounded by the epidermis and cuticle with the intestine and gonad housed within the pseudocoelomic cavity. Images modified from those found at www.wormatlas.org (Altun et al. 2002-2015). 
Self-fertilizing hermaphrodites provide several advantages for genetic analysis. First, self- fertilization (often referred to as selfing) simplifies maintaining stocks because a single animal can give rise to an entire population. Second, as Sydney Brenner (1974) has written, "the animals are driven to homozygosity," i.e., populations of hermaphrodites tend to lose heterozygotes (because hermaphrodites cannot mate with other hermaphrodites). Thus, strains that are mutagenized are essentially isogenic. Third, selfing follows the standard Mendelian rules of segregation, so a parent that is heterozygous for a recessive trait will produce the standard 1:2:1 pattern of segregation, such that $25 \%$ of the progeny will be homozygous for the mutant allele and display the autosomal recessive trait. Thus, selfing reduces greatly the effort needed to find such mutants. Fourth, mutants with neuromuscular defects that impair the ability to mate can still be maintained in the laboratory. In fact, only eleven of the 302 nerve cells of the hermaphrodite: eight ADF, ASG, ASI, and ASJ neurons, which when killed as a group cause the animals to become dauer larvae (Bargmann and Horvitz 1991), the two CAN cells (Forrester and Garriga 1997), and the M4 neuron in the pharynx (Avery and Horvitz 1989) are known to be essential to support development to the reproductive adult stage. Fifth, the viability of even severely defective mutants and their ability to self-fertilize allows for easy screens for modifier (enhancer and suppressor) mutations. Such screens have been exceptionally useful and informative. For example, lin-12 mutants (C. elegans nomenclature is outlined in Box 1) are defective in vulval development and components of the LIN-12/Notch signaling pathway have been identified with both suppressor and enhancer screens (Greenwald and Kovall 2013).

\section{Box 1. C. elegans Nomenclature}

Genetic nomenclature differs from species to species. Here, we describe the major terms used in C. elegans research. A more complete description can be found at http://www.wormbase.org/about/userguide/nomenclature.

\begin{tabular}{|c|c|}
\hline Nomenclature at a glance $^{1}$ : & Definition \\
\hline ZK154.3 & $\begin{array}{l}\text { Systematic gene identification }\left(3^{\text {rd }} \text { ORF on cosmid }\right. \\
\text { ZK154) }\end{array}$ \\
\hline mec-7 & $\begin{array}{l}\text { Gene name (the } 7^{\text {th }} \text { "mechanosensory abnormality" gene } \\
\text { named) }\end{array}$ \\
\hline$m e c-7(e 1506)$ & $\begin{array}{l}\text { Allele name (from the MRC Laboratory of Molecular } \\
\text { Biology }-e \text { ) }\end{array}$ \\
\hline MEC-7 & Protein name (product of $m e c-7$ gene) \\
\hline Mec & Phenotype (Mechanosensory abnormal phenotype) \\
\hline$e 1506$ & Homozygous allele \\
\hline$e 1506 /+$ & Heterozygous allele \\
\hline$m n D p 30$ & Duplication (from the Herman Lab - $m n$ ) \\
\hline$n D f 6$ & Deficiency/Deletion (from the Horvitz Lab $-n$ ) \\
\hline muIs35 & Integrated transgene (from the Kenyon Lab - $m u$ ) \\
\hline$e v E x I$ & $\begin{array}{l}\text { Extrachromosomal transgene array (from the Culotti Lab } \\
-e v \text { ) }\end{array}$ \\
\hline CB3270 & $\begin{array}{l}\text { Strain name (from MRC Laboratory of Molecular } \\
\text { Biology - CB) }\end{array}$ \\
\hline$m e c-7 p:: g f p$ & $\begin{array}{l}\text { GFP transcriptional fusion (using only the promoter of } \\
\text { the gene) }\end{array}$ \\
\hline$m e c-7: \because g f p$ & $\begin{array}{l}\text { GFP translational fusion (in which } g f p \text { is inserted in the } \\
\text { coding sequence of the gene) }\end{array}$ \\
\hline ceh-6(pk33::Tcl) & Transposon (Tc1) insertion in ceh-6 gene \\
\hline
\end{tabular}

${ }^{1}$ All C. elegans gene names, allele designations, and reporter genes are written in italics. Cosmids, proteins, phenotypes, and strain names are not written in italics.

Mutation (allele) names: The wild-type allele of any gene is designated by an italicized plus sign, + . Mutant alleles are represented by 1-3 lowercase letters, which indicate specific laboratories, followed by a number. All gene and allele symbols are italicized, e.g., unc-54, e678, and mn5. The homozygous genotype is represented by a 
single copy of the allele name (e678). A heterozygous condition is indicated with a slash, e.g., e364/+, e364/e1099. Chromosomal abnormalities are indicated by one or two letters after the lab code, e.g., mnDp30 is a duplication, $n D f 6$ is a deletion (called a deficiency), and $s z T 1$ is a translocation. One or two letters may be added after the allele name to indicate particular properties conveyed by the mutation e.g. temperature-sensitivity (ts), amber (am), revertant (r), dominant (d), and semidominant (sd). When a gene has more than one mutation, such as could result from the intragenic reversion of a mutant allele, both the old and new mutations are indicated, e.g., intragenic reversion of $e 1498$ could yield $e 1498 u 124 r$.

Gene names: Genes are designated by 3 or 4 lower case letters, a dash, and a number (all italicized), e.g. lon-2 and ensh-1. To distinguish alleles of the same gene, the allele names are placed in parenthesis with no space between the gene and allele name, e.g., mec-7(e1343) and mec-7(e1506). Genes that have been identified as an open reading frame (ORF) through bioinformatics approaches get a systematic gene identification (e.g. ZK154.3) until subsequent studies prompts them to be given a gene name. The upstream promoter region of a gene is indicated by the gene name followed by a "p." The promoter and the protein-coding names are separated by two colons as are parts of fusion proteins. Thus, a gene encoding a MEC-7::GFP translational fusion driven from the mec-7 promoter would be mec-7::gfp, whereas a $m a b-5$ transcriptional fusion would be $m a b-5 p:: g f p$. A transposon insertion into a gene is similarly shown using the transposon name and two colons, e.g., unc-22::Tc1 [most C. elegans transposons are labeled Tc (transposon, Caenorhabditis) and a number].

Phenotypes: Mutant phenotypes are designated by the non-italicized gene name without the dash and number and with the first letter capitalized, e.g., Unc or Sma animals are Uncoordinated or Small in body size.

Gene products: RNAs are designated by the italicized gene name; proteins are designated by the gene name in all caps and not italicized (MEC-7). Sometimes specific amino acid changes are indicated.

Strain names: Two capital letters and a number, e.g. CB429 and TU38, designate a strain containing one or more genetic differences. The letters indicate the laboratory that constructed the strain

(http://www.cbs.umn.edu/research/resources/cgc/lab-head). None of these symbols are italicized. Because a given strain can carry more than one mutation, strain names can be thought of as shorthand to describe animals carrying complicated genotypes. Genes (and/or alleles) in strains with several mutations are listed in chromosome and then map order with genes on the same chromosome separated by spaces and genes on different chromosomes separated by semi-colons. The italicized name of the chromosome can also be included, e.g., lon-2(e678) mec-7(e1506) X, unc-54; myo-3, and e364; e66; u38/szT1. szT1 is one of many balancer chromosomes that are often used to maintain mutations that are lethal as homozygotes but viable as heterozygotes. For strains that contain reporter genes, there are two typical designations. The reporters are named for specific laboratories similar to mutant alleles, and they are further named according to whether the reporter gene is maintained extrachromosomally on a multicopy array using an "Ex" label (e.g. evExl) or is maintained by integrating the sequence (in most cases randomly) into the genome using an "Is" label (e.g. muIs35).

Males are important because they allow the exchange of genetic material needed to generate animals with different genetic compositions and to map genes. Indeed, the animal has evolved to take advantage of the genetic contribution of rare males by using male (outcross) sperm before using hermaphrodite (self) sperm (Ward and Carrel 1979). Thus, if males are capable of mating, cross progeny prevail (to help males find hermaphrodites, researchers use Petri plates with a small spot of bacteria).

\subsection{Life cycle}

C. elegans embryogenesis takes approximately 16 hours at $20^{\circ}$ (all of the subsequent times are also for development at $20^{\circ}$ ) (Figure 2). A virtually impermeable eggshell is made after fertilization, allowing the embryo to develop completely independent of the mother. However, embryos are usually retained within the hermaphrodite until about the 24-cell stage at which time they are laid. The hermaphrodite embryo hatches with 558 nuclei (some nuclei are in multi-nuclear syncytia, so the cell count is lower) and becomes a first stage (L1) larva. The animals begin to eat and develop through four larval stages (L1-L4). The L1 stage is $\sim 16 \mathrm{hr}$ long; the other stages are $\sim 12 \mathrm{hr}$ long. Each stage ends with a sleep-like period of inactivity called lethargus (Raizen et al. 2008) in which a new cuticle (outer collagenous layer) is made. Lethargus ends with the molting of the old cuticle. Approximately $12 \mathrm{hr}$ after the L4 molt, adult hermaphrodites begin producing progeny for a period of 2-3 days until they have utilized all of their self-produced sperm; additional progeny can be generated if the sperm-depleted hermaphrodite mates with a male. After the reproductive period, hermaphrodites can live several more weeks before dying of senescence. 
When bacteria are depleted and the animals are crowded, L2 larvae activate an alternative life cycle (Hu 2007) and molt into an alternative L3 larval stage called the "dauer" larva ("dauer" in German means "lasting"; the signal is actually processed by L1 animals, but its results are not seen until the so-called "L2d" stage; Golden and Riddle 1984). The dauer larva cuticle completely surrounds the animal and plugs the mouth preventing the animal from eating and thereby arresting development. The dauer cuticle has enhanced resistance to chemicals, so it provides the dauer with greater protection against environmental stresses and caustic agents. Dauer larvae can survive for many months and are the dispersal form most commonly encountered in the wild. When the dauer larvae are transferred onto plates with bacteria, they shed their mouth plugs, molt, and continue their development as slightly different L4 larvae.

\section{C. elegans genetics}

A major reason Sydney Brenner (Brenner, 1974) chose to study C. elegans was the ease of genetic manipulation. Self-fertilization means that after hermaphrodites ( $\mathrm{P} 0 \mathrm{~s})$ are mutagenized, any mutant alleles (except dominant lethals) can be maintained through self-propagation in first-generation (F1) progeny, second-generation (F2) progeny, etc. without mating. This property makes obtaining these progeny easy. In practice, C. elegans researchers screen for mutations anywhere in the genome (instead of using balanced strains to mutagenize single chromosomes) in a single mutagenesis and determine linkage afterward. A second genetic advantage of $C$. elegans is that it grows quickly. Since animals take $\sim 3$ days at $25^{\circ}\left(\sim 3.5\right.$ days at $\left.20^{\circ}\right)$ to develop from fertilized eggs to adults producing their own fertilized eggs, mutant homozygotes can be detected two generations $(\sim 1$ week $)$ after mutagenesis. In addition, the ability to freeze and recover $C$. elegans makes it possible to preserve mutant strains without worrying that they have acquired unwanted suppressors, other modifiers, or additional background mutations or have lost important mutations, particularly if they are maintained as heterozygotes. Therefore, much less effort needs to be devoted to strain maintenance.

The traditional use of genetics in C. elegans (often referred to as "forward genetics") begins with a screen or selection to find mutants with a particular phenotype followed by inference of the wild-type role of the gene from the nature of the mutant phenotype. Jorgensen and Mango (2002)have reviewed the many types of screens and selections used in C. elegans to identify mutations resulting in novel phenotypes (including conditional phenotypes) and mutations that modify (either enhancing or suppressing) existing phenotypes. A variety of mutagens have been used (Kutscher and Shaham 2014), including ethane methylsulfonate (EMS), an alkylating reagent that causes principally GC-to-AT transition mutations and small deletions, used by Brenner in his initial studies (Brenner 1974).

Once mutant strains have been obtained and shown to be true-breeding, i.e., give mutant individuals in the next generation, they can be mapped using classical genetic tools (Brenner 1974). Originally, mapping involved linkage crosses to identify the chromosome containing the mutation followed by multiple three-factor crosses to refine its map position. Once a map position had been determined, the mutated gene could be identified molecularly (using the physical map of overlapping genomic clones) by transformation rescue of the mutant phenotype by the wild-type gene (Evans 2006; Merritt et al. 2010; Schweinsberg and Grant 2013). Transformation requires injection of DNA into the syncytial (multi-nucleated) gonad, where it is incorporated into the nucleus of some developing gametes (Mello and Fire 1995). Transposon-tagged mutations were also used to isolate the DNA of the mutated gene, allowing for its molecular identification (e.g., Greenwald 1985). The entire process of cloning a gene could easily take a year.

Today, however, the process of connecting a mutant phenotype to a gene is much more rapid due to advances in whole-genome sequencing (Doitsidou et al. 2010; Zuryn et al. 2010; Minevich et al. 2012). Mutants derived from the standard wild-type strain (called N2) are crossed to a wild-type strain obtained in Hawaii (CB4856), whose sequence differs from N2 at many positions [one single nucleotide polymorphism (SNP) per $91+/-56 \mathrm{~kb}$; Swan $e t$ al. 2002]. Mutants re-isolated after the cross have retained N2 sequences in the vicinity of the mutation, whereas $\mathrm{N} 2$ and Hawaiian sequences randomly segregate at other loci. Whole-genome sequencing can reveal the location of N2 DNA and lead, hopefully, to a small number of candidate genes that can be tested as above. This process can be done in a number of weeks and, as before, transformation rescue (or complementation testing) provides evidence that the correct gene has been identified.

Researchers can also use a known gene sequence to obtain mutant strains, a process called "reverse genetics" (Ahringer 2006). One of the first ways to do such reverse genetics was the generation of strains that deleted all or part of a target gene (Lesa 2006). Animals were mutagenized with trimethylpsoralen to cause deletions and large numbers of individual F2 animals were used to establish lines. Pooling DNA from these strains and amplifying the 
several pools of DNA with PCR primers, designed to amplify a deleted but not wild-type gene, could identify which line had a deletion mutation (a process called sibling-selection). Further selection within the line could establish a homozygous strain containing the deletion mutation.

Whole-genome sequencing has enabled a very rapid way of obtaining mutations. In a study dubbed the "million mutation project" (Thompson et al. 2013), animals were mutated by EMS and/or N-ethyl-N-nitrosourea (ENU) and F2 progeny (from different P0 parents) were grown. Over 2000 healthy strains were established from these mutageneses. Whole-genome sequencing of each strain showed that, on average, there were 400 mutations per strain. Altogether these strains had over 800,000 unique mutations. Since the genome contains $\sim 20,000$ genes, each gene has been mutated an average of 8 times. The results are available in WormBase and the strains can be obtained from the Caenorhabditis Genetics Center (Table 1). Recent advances in efficient genome-editing methods (TALEN and CRISPR/Cas9) in C. elegans now allow investigators to create targeted mutations in nearly any location in the genome in any genetic background (Frøkjær-Jensen 2013, Waaijers and Boxem 2014). These gene editing techniques, particularly CRISPR/Cas9, enable rapid methods to mutate and interrogate C. elegans genes, and new approaches based on them are being introduced.

TABLE 1 C. elegans resources

\begin{tabular}{|c|c|c|}
\hline Resource & Website Address & Description \\
\hline WormBase & http://www.wormbase.org/ & $\begin{array}{l}\text { Genes, expression, resources, phenotypes, } \\
\text { metadata, and publications }\end{array}$ \\
\hline WormBook & http://www.wormbook.org/ & $\begin{array}{l}\text { Basic information about the biology of } C \text {. } \\
\text { elegans and other nematodes, including } \\
\text { methods }\end{array}$ \\
\hline WormAtlas & http://www.wormatlas.org/ & $\begin{array}{l}\text { Worm anatomy, including neurons and } \\
\text { wiring, EM sections, and cell lineage }\end{array}$ \\
\hline $\begin{array}{l}\text { Caenorhabditis Genetics } \\
\text { Center }\end{array}$ & $\begin{array}{l}\text { https://www.cbs.umn.edu/ } \\
\text { research/resources/cgc }\end{array}$ & $\begin{array}{l}\text { Stocks of wild-type and mutant nematode } \\
\text { strains }\end{array}$ \\
\hline $\begin{array}{l}\text { National Bioresource } \\
\text { Project }\end{array}$ & $\begin{array}{l}\text { http://www.shigen.nig.ac.jp/ } \\
\text { c.elegans/index.jsp }\end{array}$ & Collection of deletions of C. elegans genes \\
\hline Million Mutation Project & http://genome.sfu.ca/mmp/ & $\begin{array}{l}\text { Fully sequenced genomes of strains carrying } \\
\text { multiple mutations }\end{array}$ \\
\hline $\begin{array}{l}\text { Expression patterns } \\
\text { database }\end{array}$ & http://gfpweb.aecom.yu.edu/index & $\begin{array}{l}\text { Expression patterns for promoter::gfp } \\
\text { transgenes }\end{array}$ \\
\hline TransgeneOme & $\begin{array}{l}\text { https://transgeneome.mpi-cbg.de/ } \\
\text { transgeneomics/index.html }\end{array}$ & $\begin{array}{l}\text { Resource for tagged gene constructs and } \\
\text { expression patterns }\end{array}$ \\
\hline modENCODE & Www.modencode.org & Model organism database of DNA elements \\
\hline UCSC Genome Browser & https://genome.ucsc.edu/ & $\begin{array}{l}\text { Multiple alignments of conserved nematode } \\
\text { genome sequences }\end{array}$ \\
\hline $\begin{array}{l}\text { C. elegans Interactive } \\
\text { Network }\end{array}$ & http://www.wormweb.org/ & $\begin{array}{l}\text { Interactive neuron wiring diagram and gene } \\
\text { expression information with direct links to } \\
\text { published supporting data }\end{array}$ \\
\hline OpenWorm Science & http://www.openworm.org/ & $\begin{array}{l}\text { Various on-line resources for C. elegans } \\
\text { research. }\end{array}$ \\
\hline $\begin{array}{l}\text { C. elegans Behavioral } \\
\text { Database }\end{array}$ & http://wormbehavior.mrc-lmb.cam.ac.uk/ & $\begin{array}{l}\text { Detailed traces of worm movement and } \\
\text { posture for different strains and mutants }\end{array}$ \\
\hline $\begin{array}{l}\text { Caenorhabditis briggsae } \\
\text { Research Resource }\end{array}$ & http://www.briggsae.org/ & Resource for research on C. briggsae \\
\hline $\begin{array}{l}\text { Nematode and Neglected } \\
\text { Genomics }\end{array}$ & http://www.nematodes.org/ & $\begin{array}{l}\text { Database of genomics for other nematode } \\
\text { species }\end{array}$ \\
\hline
\end{tabular}




\begin{tabular}{|l|l|l|}
\hline Resource & Website Address & Description \\
\hline Rhabditina Taxonomy & $\begin{array}{l}\text { http://128.122.60.136/fmi/iwp/ } \\
\text { cgi?-db=RhabditinaDB\&-loadframes or } \\
\text { http://wormtails.bio.nyu.edu/ } \\
\text { Databases.html }\end{array}$ & $\begin{array}{l}\text { Nematode phylogeny, morphology, } \\
\text { literature, ecology, and geographical } \\
\text { information }\end{array}$ \\
\hline WormClassroom & http://wormclassroom.org/ & Resource for education using C. elegans \\
\hline
\end{tabular}

Mutant-like phenotypes can also be obtained using RNA interference (RNAi), the use of double-stranded RNA (dsRNA) to reduce gene activity (Fire et al. 1998; see Ahringer 2006). The added discovery that RNAi can be produced by soaking the animals in a solution of dsRNA (Tabara et al. 1998)or by feeding the animals bacteria that generate specific dsRNA (Timmons and Fire, 1998)means the entire genome can be easily and systematically interrogated for genes needed for specific functions. Such genome-wide screens using libraries of bacterial strains are common and easily done.

\section{Why choose $C$. elegans?}

In addition to being a powerful system for genetic studies, $C$. elegans has many inherent advantages as a model for eukaryotic biology. These features include its small size, large brood size, ease of cultivation, low maintenance expense, long-term cryopreservation, quick generation time, transparency, invariant cell number and development, and the ability to reduce gene activity using feeding RNAi. Although not usually mentioned, another favorable feature of $C$. elegans is the organisms are quite benign to humans. In fact, because they cannot grow at body temperatures, they cannot grow in humans. Some nematodes, e.g., Ascaris suum, induce a debilitating allergic reaction and must be studied in ventilated hoods (Kennedy 2013; A.O. Stretton, personal communication). As far as we are aware, allergic reactions to C. elegans have not been documented.

Studies of cell and developmental biology that use $C$. elegans are greatly aided by the transparency of the animal, which allows researchers to examine development and changes due to mutations or altered environments at the level of a single, identified cell within the context of the entire living organism. Thus, many biological problems can be studied "in miniature" at the single-cell level, instead of large numbers of cells in heterogeneous tissues. Transparency also enables a wealth of studies in living animals utilizing fluorescent protein reporters (Figure 1D and Figure 4B). By labeling cells and proteins in living cells, fluorescent proteins enable genetic screens to identify mutants defective in various cellular processes. In addition, fluorescent protein-based reporters (e.g., Cameleon and gCaMP3; Figure 4C), which fluoresce in response to calcium flux, provide neuron-specific detection of calcium flux under a fluorescent microscope, and therefore allow researchers to measure electrophysiological activity in vivo (Kerr 2006). Furthermore, mapping of cell-cell and synaptic contacts can be accomplished by expressing complementary fragments of GFP in different cells (GRASP; Feinberg et al. 2008). Transparency also means that optogenetic tools, which alter the activity of individual neurons, are particularly effective in C. elegans (Husson et al. 2013). In all of these experiments, greater control of the animal's position and environment can be accomplished by microfluidic devices in which individual worms are mounted in custom-designed channels allowing the application of various compounds or other agents while simultaneously monitoring fluorescent readout of gene regulation or electrophysiological activity by microscopy (Lockery 2007; San-Miguel and Lu 2013). 

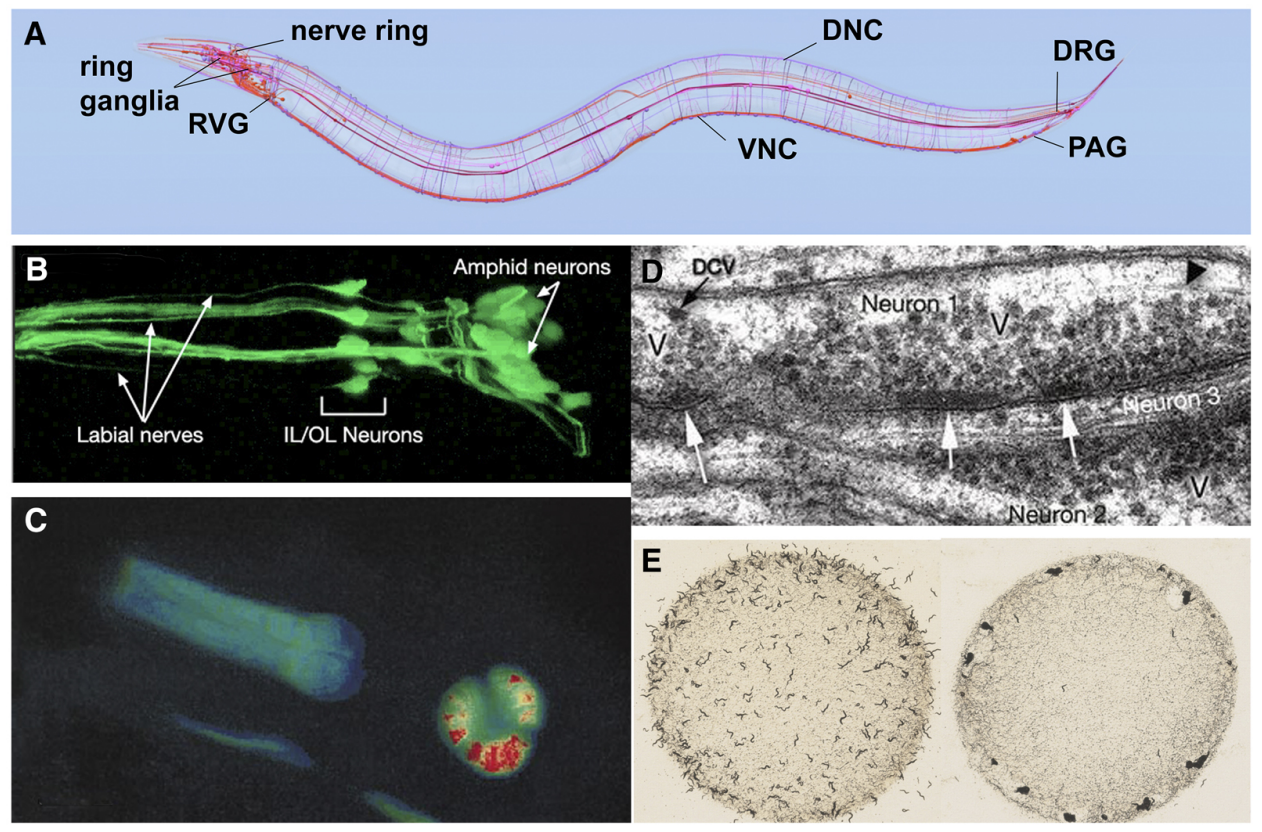

Figure 4. Anatomy and study of the $C$. elegans nervous system. (A) Diagram of the $C$. elegans nervous system identifying some major nerve bundles and ganglia. Major nerve tracts include the ventral nerve cord (VNC), dorsal nerve cord (DNC), and nerve ring. Major ganglia include the ring ganglia, retrovesicular ganglion (RVG), pre-anal ganglion (PAG), and dorsal-root ganglion (DRG). Image produced using the OpenWorm browser utility (openworm.org). (B) Visualization of anterior sensory neurons and their neurite projections by expression of a GFP reporter transgene. The Y105E8A.5::GFP fusion transgene is expressed in amphid, OL, and IL sensory neurons of the head (R. Newbury and D. Moerman, Wormatlas; wormatlas.org). (C) Use of cameleon reporter transgene to detect calcium transients in the C. elegans pharynx. The animal carries a transgene with myo-2, a pharynx-specific myosin gene, fused to YC2.1, a calcium-sensitive fluorescent detector. False-color red in the pharyngeal bulb reflects real-time calcium releases in the cell of the living animal. Image adapted from Kerr et al. (2000). (D) Electronic microscopic section showing synapses. Collections of densely-staining vesicles can be seen in neuron 1 at point of synaptic connection to neurons 2 and 3 (arrows). Synaptic varicosities (V) that contain vesicles can be seen clustered around the active zone. DCV identifies a dense-core vesicle. Image from D. Hall (Wormatlas; wormatlas.org). (E) Worm behavior on a bacterial plate. Left image shows the standard laboratory N2 strain foraging as individuals evenly dispersed across the bacterial food. Right image shows an $n p r-1$ mutant strain foraging in grouped masses (sometimes called a "social" feeding phenotype). Image from M. de Bono, taken from Schafer (2005).

Sharing large amounts of genetic and cellular information has been central to the success of $C$. elegans research. The wealth of knowledge generated by past research is readily available to anyone via on-line resources (see Table 1). Much of this information, including gene expression, gene function, and references, is curated on WormBase (www.wormbase.org). Reviews on many topics of C. elegans biology are provided by WormBook (www.wormbook.org), which includes a collection of $C$. elegans methods (WormMethods) and current and past issues of the C. elegans Newsletter (The Worm Breeder's Gazette).

No model organism can be used to answer every research question, and working with $C$. elegans has some limitations. Not all metazoan genes are found in the C. elegans genome (Ruvkun and Hobert 1998). For example, Hedgehog (Hh) signaling is important in vertebrates for the patterning of various organs during development, but $C$. elegans lacks many of the genes in the regulatory cascade (Bürglin and Kuwabara 2006). Although some C. elegans cells can be studied in vitro [e.g., embryonic glial cells, larval muscle, and neuronal cells (Zhang et al. 2011; Stout and Parpura 2012)], no C. elegans cell culture lines exist. The small size of the animal and its cells also provides a challenge since experimental manipulation in individual tissues of an organism that is less than a millimeter long is difficult. Electrophysiology of C. elegans neurons and muscle is possible, but demanding (Raizen and Avery 1994; Lockery and Goodman 1998 Cook et al. 2006; Richmond 2006)and indirect measurements of neuronal activity, such as calcium imaging are often used instead (Kerr 2006). Finally, biochemical approaches in C. elegans have lagged behind the genetic approaches, but the development of an axenic culture medium for $C$. elegans (e.g., Rao et al. 2005)has meant that biochemical studies can be done on animals under defined conditions.

\section{C. elegans tissues}

One attractive feature of $C$. elegans is that despite its simplicity, it has defined tissues. The animal is often described as a series of concentric tubes (Figure 3C). The outer layer of cells, the epidermis (traditionally called the hypodermis) encloses a pseudocoelomic fluid-filled cavity housing the main organ systems. Just inside the epidermis are the bands of muscle, which control movement of the organism, as well as the ventral and dorsal nerve 
cords that innervate the muscles. Inside the neuro-muscular region are the digestive, excretory, and reproductive systems. In addition, $C$. elegans has six cells in the pseudocoelomic cavity, called coelomocytes, which act as scavengers in the body cavity (Grant and Sato, 2006). These cells behave similarly to vertebrate macrophages (although they have a fixed position within the animal), are highly active in endocytosis, and are thought to sort through and clear material in the pseudocoelomic cavity of the animal. More extensive descriptions of these systems with beautiful electron micrographs of the various cell types can be found in WormAtlas (www.wormatlas.org). Here, we will cover some of the basic aspects of the anatomy, particularly with respect to how the organ systems are advancing the understanding of cell and developmental biology.

\subsection{Epidermis: a model for extracellular matrix production, wound healing, and cell fusion}

The outer epithelial layer, the epidermis, of the embryo undergoes a series of cell fusions to make large multinucleate, or syncytial, epidermal cells. These cells secrete the cuticle, a protective layer of specialized extracellular matrix (ECM) consisting primarily of collagen, lipids, and glycoproteins (Chisholm and Hardin 2005; Page and Johnstone 2007). The cuticle determines the shape of the body and, through connection from the epidermis to muscle, provides anchoring points for muscle contraction (Figure 5A). The cuticle also serves as a model for ECM formation and function with molecules and pathways involved in cuticle biogenesis conserved in vertebrates (Page and Johnstone 2007).
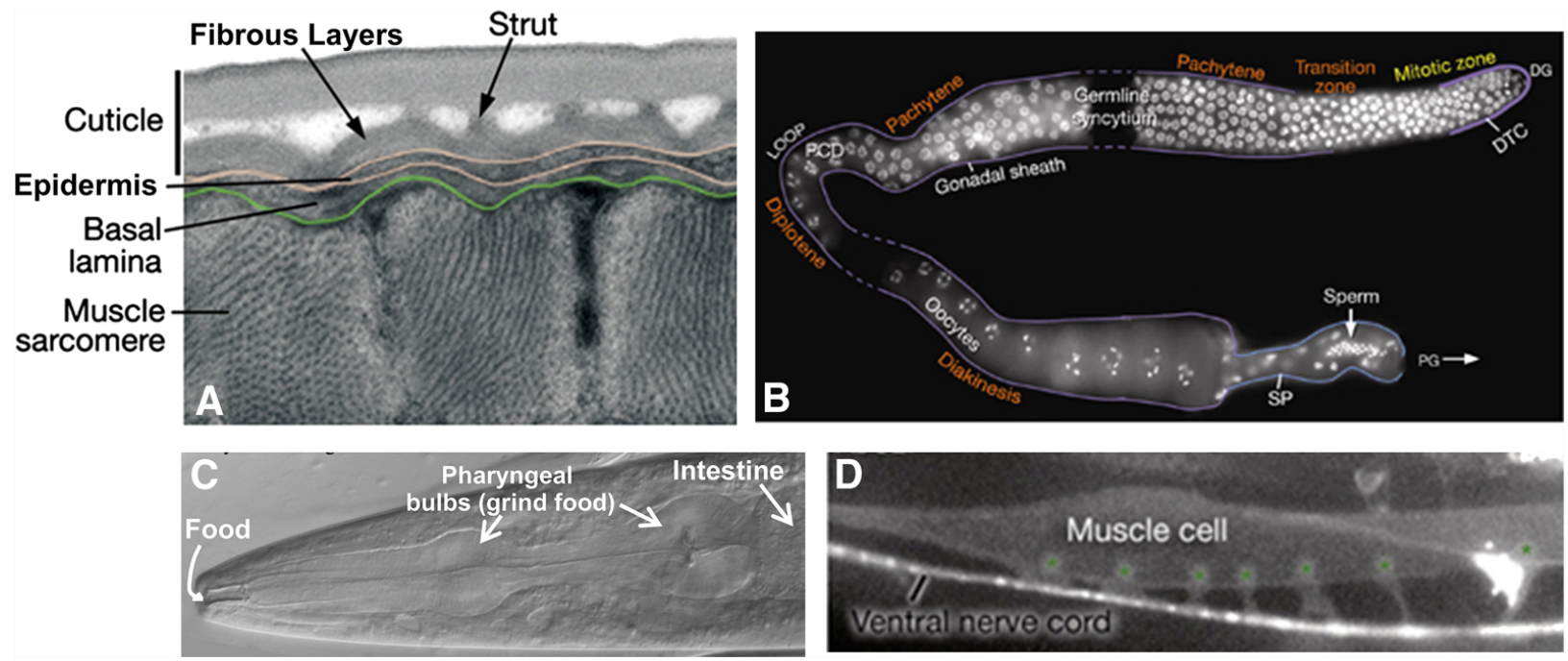

Figure 5. C. elegans tissue morphology. (A) Cross section of the outer layers of the animal showing muscle cells below the epidermis and cuticle viewed by transmission electron microscopy. (B) Single gonad arm dissected out of a hermaphrodite showing germ cell DNA (stained white). Meiosis begins in the region labeled Pachytene (upper right) and continues around the loop of the gonad until oocytes are formed. The stored sperm are located in the spermatheca of the gonad (bottom right). This image is a composite of 3 gonad arms and dashed lines represent regions not captured in the individual micrographs. (C) The anterior of the animal showing the mouth where food enters, the pharynx with its two bulbs, and the beginning of the intestine viewed with differential interference contrast (DIC). (D) A single body wall muscle cell with 6 muscle arms (marked with asterisks) extending to the ventral nerve cord (lateral view). The micrograph shows fluorescence from both muscle and neuronal GFP reporters [him-4p::MB::YFP (muscle), hmr-1b:: DsRed2 (neuron) and unc-129nsp:: DsRed2 (neuron)]. All images are modified from WormAtlas (www.wormatlas.org). Photo credits: (A) D. Hall, (B) J. Maciejowski and E. J. Hubbard, and (C and D) WormAtlas.

Mutations in several genes needed for cuticle formation produce visible phenotypes (Figure 6). Mutations in collagen genes can result in animals that move in a corkscrew fashion [the Roller (Rol) phenotype] or that have normal width but reduced length [the Dumpy (Dpy) phenotype]. Other mutations affect the struts formed between layers of the adult cuticle, resulting in fluid-filled blisters [the Blister (Bli) phenotype]. Still other mutations make the animals longer than normal [the Long (Lon) phenotype]. At the end of each larval stage (Figure 2), C. elegans sheds its cuticle and secretes a new one to accommodate the growing organism. Genes involved in cuticle formation are regulated so that the cuticle is reestablished after each molt. 


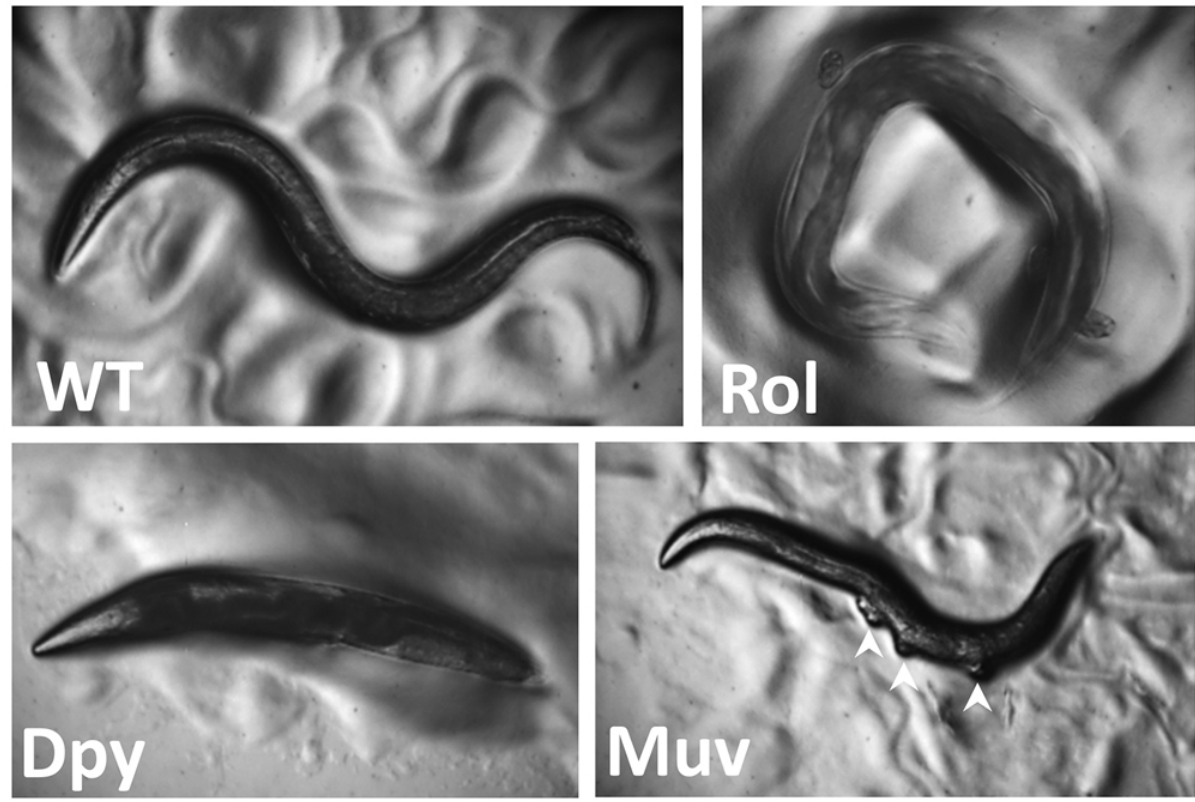

Figure 6. C. elegans mutant phenotypes. Wild-type animals (WT) are approximately $1 \mathrm{~mm}$ long with a smooth exterior, and they move in a sinusoidal pattern. Rolling (Rol) animals twist their body like a corkscrew and as a result often remain in the same region moving in a circular pattern. Dumpy (Dpy) animals are shorter than wild-type. Multivulvae (Muv) hermaphrodites have protrusions along the ventral side (white arrowheads) where vulvae form but are not able to attach to the uterus. Strain sources: D. Eisenmann and A. Golden.

Studying the epidermis has led to insights in early cell movements, wound healing, cell-cell fusions, and the establishment of epithelial layers in developing embryos (Chisholm and Hardin 2005; Podbilewicz 2006). As the "skin" of C. elegans, the epidermis is a model for the innate immune response to pathogens and for repair after a physical wound such as a needle puncture. The wounded epidermis upregulates both $\mathrm{Ca}^{\text {+⿱ }}$ signaling to direct actin polymerization for repair and innate immune signaling pathways to help promote survival after injury (Xu et al. 2012). The cell-cell fusion events leading to the multinucleate epidermis and genes important for this process have been studied (Podbilewicz 2006). This work has supported the idea that repression of fusion in some cells may be just as important for proper development as activation of cell fusion in other cells (Podbilewicz 2006).

\subsection{Muscles-controlling animal movement}

Just interior and connected to the epidermis are four quadrants ( 95 cells) of body-wall muscles that run along the length of the body (Figure 3). The regular contraction and relaxation of the muscle cells leads to the "elegant" sinusoidal movement of the animal. These somatic muscles are striated (although, unusually, they are obliquely striated) and mononucleate (muscle cells do not fuse as they do in vertebrates) with multiple sarcomeres per cell (Moerman and Fire 1997). The innervation of these muscles is also unusual in that the muscle cells send extensions ("muscle arms") to the ventral and dorsal cord to receive en passant synapses from the motor neurons instead of the more usual case of receiving axonal projections from motor neurons (White et al. 1986; Figure 5D).

Genetic studies of muscle led to the first cloning and sequencing of a myosin gene (unc-54; MacLeod et al. 1981), and this finding provided major insights into the structure of all myosins. unc-54 and many other unc (uncoordinated) genes encoding proteins needed for muscle activity produce a "floppy paralytic" phenotype (Hodgkin 1983). The study of the assembly of sarcomeres into functional muscles and, in particular, the proteins mediating attachment to the plasma membrane has revealed many molecules in common with vertebrate focal adhesion complexes (Moerman and Williams 2006). Genetic screens designed to understand molecules involved in muscle contraction have also led to insights regarding muscle-wasting diseases such as Duchenne's Muscular Dystrophy (Chamberlain and Benian 2000)and cardiomyopathies (Benian and Epstein 2011). In addition to the body-wall muscle, $C$. elegans has muscles that control eating (pharyngeal muscles), egg-laying (vulval and uterine muscles and the contractile gonad sheath), mating (male-specific tail muscles), and defecation (enteric muscles). 


\subsection{The digestive system-a model for organogenesis and pathogenesis}

Food (bacteria) enters the anterior of the animals and passes through the pharynx, a two-lobed neuromuscular pump that grinds the food before it is passed on to the intestine for digestion (Figure 5C; Avery and You 2012). The pumping behavior of the animals depends on the availability and the quality of the food; for example, animals pump more when hungry and less when full (Avery and Shtonda 2003). Studying pharyngeal development has been a model for organogenesis, including how epithelial morphogenesis and cell-fate specification occur during development (Mango 2007). For example, the transcription factor PHA-4 plays a major regulatory role in the organ identity of the pharynx (Mango et al. 1994). Animals defective in PHA-4 function do not contain a pharynx and embryos that overexpress PHA-4 have more pharyngeal cells (Mango 2007). The vertebrate FoxA transcription factors are homologous to PHA-4 and are involved in gut development in many species (Carlsson and Mahlapuu 2002).

The C. elegans intestine is attached to the posterior pharynx and consists of 20 large, polyploid epithelial cells arranged in pairs that form a tube running the length of the animal. Intestinal development has been studied in detail (McGhee 2007). Presumably to handle the increasing demands of the growing animal, the intestinal cells undergo one round of nuclear division during the first larval stage and subsequent rounds of DNA replication, but not nuclear division, in the later larval stages (Hedgecock and White 1985). C. elegans has served as a model to study infection and response to infection by several different bacterial pathogens, microsporidia, and viruses that colonize the digestive system (Darby 2005; Balla and Troemel 2013; Diogo and Bratanich 2014).

\subsection{The nervous system-small yet complex}

C. elegans has become an important model for the study of neurobiological questions. Researchers have identified genes and mechanisms needed for neuronal generation and specification, cell death, precursor migration, synapse formation, chemosensory and mechanosensory transduction, neuronal degeneration, neurite regeneration, and glial function (Driscoll and Chalfie 1992; Silhankova and Korswagen 2007; Hammarlund and Jin 2014; Shaham, 2015). Researchers also have investigated a variety of behaviors, both simple and complex, including chemotaxis, thermotaxis, several responses to touch, male-specific mating rituals, social feeding, and both associative and non-associative learning (Bargmann 2006; Hart 2006; Barr and Garcia 2006; Ardiel and Rankin 2010; Figure 4E). C. elegans also experiences periods of restful inactivity that are similar to aspects of mammalian sleep (Raizen et al. 2008).

The nervous system of the adult hermaphrodite has 302 neurons (Sulston and Horvitz 1977; White et al. 1986); that of the adult male has 383 neurons (Figure 4; WormAtlas.org). The majority of neuronal cell bodies are arranged in a few ganglia in the head, in the ventral cord, and in the tail (the specialized male tail has the majority of the extra neurons). Most of the neurons have a simple structure with one or two neurites (or processes) exiting from the cell body, but a few cells, such as the FLP and PVD mechanosensory neurons, have elaborately branched neurites (Dong et al. 2013). Except for sensory dendrites, which are often easy to identify, most neurites cannot be distinguished as axons or dendrites because they both give and receive synapses (although they are often referred to as "axons"). The neurites form synapses to each other in four major areas: the nerve ring (which encircles the pharynx), the ventral nerve cord, the dorsal nerve cord, and the neuropil of the tail. In addition to neurons, $C$. elegans has several glia-like support cells, which are primarily associated with sensory neurons, but are not as numerous as in vertebrates (Oikonomou and Shaham 2010).

Nerve conduction in $C$. elegans appears to be primarily passive. No sodium-dependent action potentials have been detected in neurons (Goodman et al. 1998)and the genome has no genes for voltage-gated sodium channels (Bargmann 1998). The absence of action potentials may be due to the very high membrane resistance. Indeed, many neurons are essentially isopotential; changes in voltage are experienced virtually instantaneously by the entire cell (Goodman et al. 1998), so action potentials may not be necessary (Lockery and Goodman 2009). Neurons express a wide variety of ion channels (Hobert 2013), including an unexpectedly large number of genes encoding potassium channels (Salkoff et al. 2005).

C. elegans neurons make more than 7000 chemical synapses and gap junction connections (White et al. 1986). Unlike in vertebrate nervous systems, $C$. elegans neurons do not send terminal branches with boutons to make synapses. Most of the connections are made en passant (side by side as neurites pass each other), although many bilaterally symmetrical neurons join their tips together with gap junctions at the midline and some motor neurons similarly join with homologues end to end. Nematodes are unusual in that motor neurons do not send processes that 
synapse onto muscle; instead muscles send cellular projections to motor neurons to receive synapses. Chemical synapses are identified in electron micrographs by presynaptic darkening and synaptic vesicles; postsynaptic specializations are not obvious (Figure 4D). C. elegans uses many of the most common neurotransmitters, including acetylcholine, glutamate, $\gamma$-amino butyric acid (GABA), dopamine, and serotonin and has several receptors for their detection (Hobert 2013). Gap junctions are detected in electron micrographs as parallel membranes in the closely apposed neurons. As with other invertebrates, gap junctions are formed from innexins (Starich et al. 2001). In addition to the chemical synaptic and gap junction connections, $C$. elegans neurons are modulated by numerous neuroendocrine signals ( $\mathrm{Li}$ and Kim, 2008). From the perspective of cellular and molecular detail, most of the problems of neurobiology can be studied in the worm.

In C. elegans, some individual neurons perform functions that would be performed by multiple neurons in vertebrates. For example, individual olfactory neurons express multiple $\mathrm{G}$ protein-coupled odorant receptors (Troemel et al. 1995; Wes and Bargmann 2001), rather than a single receptor as in vertebrates; each of the two mirror image bilateral ASE chemosensory cells respond to several different ions (Hobert 2010); and the connectivity of the touch receptor neurons suggests that their stimulation initiates several different activities (Chalfie et al. 1985). Thus, functions of multiple vertebrate sensory neurons are compressed into a single neuron in C. elegans. This multi-functionality (or "polymodality") may be an evolutionary consequence of the small number of neurons in the C. elegans nervous system. Alternatively, multi-functionality may reflect a general feature of nervous systems that was revealed by the ability to do detailed single-cell analyses with this animal.

\subsection{Reproductive tissue-sex-specific anatomy}

The $C$. elegans sexes display several obvious anatomical differences in the somatic gonad, secondary sexual structures, and body size (Figure 2. Figure 3, A and B). The somatic gonad is located in the center of the body alongside the intestine. In hermaphrodites the gonad consists of two mirror-image U-shaped tubes; in males the gonad consists of a single U-shaped lobe (Figure 3). Both gonads house the germline where the oocytes and sperm develop (Hubbard and Greenstein 2005). The somatic gonad and the germline develop together during larval stages until animals reach maturity at the young adult stage. A powerful advantage for studies of the C. elegans germline is that one can observe all stages of meiosis at once as the germline is a visible gradient of development (Hubbard and Greenstein 2005; Kimble and Crittenden 2005; Figure 5B). Studying the germline has been a model for meiosis, gamete development, fertilization, stem cell biology, and even tumor formation (Kimble and Crittenden 2005).

Secondary sexual mating structures are the vulva in hermaphrodites and the fan-shaped tail in males (Emmons 2005; Herman 2006). The vulva develops in the center of the epidermis on the ventral side of the hermaphrodite and is the conduit for sperm entry from the male and egg laying from the uterus (Sternberg 2005). Studying vulval morphogenesis has provided insights into signaling by the Notch, EGF, and Wnt pathways that coordinate the spatiotemporal development of the organ. Defects in these pathways can lead to animals with no vulva [the egg-laying defective (Egl) phenotype] or with many vulval-like protrusions [the multivulva (Muv) phenotype; Figure 6]. In many cases these animals cannot lay eggs (or mate), and their progeny develop internally, hatch within the hermaphrodite, and create the "bag-of-worms" phenotype whereby the larvae consume the mother (a process called endotokia matricidia). This phenotype, which also occurs when wild-type adult hermaphrodites are starved, has been used to identify numerous egg-laying defective mutants. For example, details of Ras GTPase/Map Kinase signaling have been elucidated through the identification of mutants in enhancer/suppressor screens of vulval phenotypes (Sundaram 2013).

Adult males are thinner than hermaphrodites (due to their smaller gonad and the absence of developing embryos), and their tails are flattened into a fan of cuticular material with 18 projections of neurons and associated support cells called rays (Figure 3B). As with vulval development, the development of male tail structures and their associated muscles involves the coordinated action of multiple signaling pathways (Emmons 2005). Interestingly, the same signaling pathways are used in both males and hermaphrodites in the development of reproductive tissues (e.g., Wnt signaling), yet these pathways produce very different sex-specific organs and structures (Emmons 2005).

The outward morphology of males and hermaphrodites is determined by a regulatory cascade that controls the transcription factor TRA-1 (Zarkower 2006). The activity of TRA-1 depends on the X to autosome (or X:A) ratio. In males, TRA-1 is inactive and leads to male fate and the production of sperm. In hermaphrodites, TRA-1 is active and leads to a female somatic fate and the formation of female gametes. C. elegans also has a dosage compensation system that down-regulates expression of genes on the X-chromosome in hermaphrodites to equalize X-linked expression between the sexes. A sex-specific dosage compensation complex, analogous to the chromatin condensin complex used in mitosis and meiosis, decorates the X chromosomes in hermaphrodites and down-regulates X-linked genes by $50 \%$ to equal the gene expression from the single X chromosome in males (Meyer 2005). 


\section{The C. elegans genome}

C. elegans was the first multicellular eukaryotic organism to have its genome sequenced (C. elegans Sequencing Consortium, 1998). As sequence information from additional Caenorhabditis species as well as more distantly-related nematodes has become available in the past decade, the information from C. elegans has provided the basis for rich comparative genomics studies (Coghlan 2005). The entire C. elegans genome is $100 \mathrm{Mb}(C$. elegans Sequencing Consortium, 1998)and has 20,444 protein-coding genes (WormBase release WS245, Oct. 2014). Both C. elegans sexes contain five autosomal chromosomes named linkage group (LG) I, II, III, IV, and V and the X chromosome. Individual genes of C. elegans are arranged in conventional eukaryotic fashion with 5 , untranslated regions, open reading frames (ORFs) containing exons and introns, and 3' untranslated regions. Compared to vertebrate genes, $C$. elegans genes are relatively small with the average gene size of $3 \mathrm{~kb}$ due primarily to the presence of very small introns (Spieth and Lawson 2006; C. elegans genes also have many normal-sized introns). The chromosomes do not contain traditional centromeres; during mitosis the microtubule spindle attaches to more than one position along the chromosome (these attachments are said to be holocentric or polycentric). In fact, a specific sequence does not seem to be required for attachment since extrachromosomal DNA-containing transgenes can be inherited throughout many cell divisions.

The C. elegans genome has two unusual aspects: most protein-coding mRNAs are trans-spliced and some genes are organized in operons (Blumenthal 2005). Trans-splicing is the addition of one of two 22-nucleotide leader sequences (SL1 and SL2) at the 5' end of mRNA. The leader sequence is believed to aid in translational initiation and, because SL1/2 sequences are known, can be used experimentally to identify the sequence at the 5 ' end of mRNAs. Some C. elegans mRNAs are formed from multigenic transcripts with the first mRNA spliced to SL1 and subsequent mRNAs to SL2. The genes that code for these transcripts are closely spaced together in tandem and are transcribed under the control of a single promoter. These transcripts are similar to those produced by bacterial operons and code for gene products that are co-expressed (Blumenthal 2005). They differ, however, in that the processed transcripts in $C$. elegans generate multiple mRNAs. Past experiments have indicated that DNA is not methylated in C. elegans, but recent, higher resolution studies have suggested that some methylation does occur (Hu et al. 2015). Aspects of gene regulation such as transcription, translation, chromatin remodeling, and post-transcriptional modifications (ubiquitination, phosphorylation, histone methylation, glycosylation) have all been studied using the genetic tools of C. elegans.

\section{Caenorhabditis ecology and evolution}

In the wild, $C$. elegans is primarily restricted to temperate regions. In contrast, related species such as $C$. briggsae, are considered "cosmopolitan" since they are found in many habitats (Kiontke and Sudhaus 2006). Although often mischaracterized as a soil nematode, larval and adult $C$. elegans have been routinely recovered from organic-rich garden soils, compost, and rotting fruit and plant stems, and only rarely from "wild" soil (Blaxter and Denver 2012; Félix and Duveau 2012). Compost-like locations are likely to be attractive to the animals because they are abundant in the bacterial food the animals need. Outside of rotting fruits and stems, C. elegans are usually found as dauer larvae, the dispersal form of the animal. Dauer larvae are unusual in that they engage in "nictating" behavior, wherein they stand on their tails and wave their heads in the air (Lee et al. 2011). This activity is thought to aid in attachment of the dauer larva to other invertebrate couriers, such as isopods, so the nematode can be dispersed from a depleted food source to a new food source (Croll and Matthews, 1977). Recent work on nematode ecology has included studies on wild population structures and competition between Caenorhabditis species (Félix and Duveau 2012)and the effect of the richness of the bacterial biomass on nematode growth (Darby and Herman, 2014). In addition, Rechavi et al. (2014)recently demonstrated that starvation in C. elegans leads to an upregulation of small RNAs that target nutrition genes and are inherited by multiple generations ("transgenerational inheritance") providing a mechanism for memory of past environmental conditions.

Caenorhabditis and other nematodes belong to the phylum Nematoda, which is part of a larger group of the clade Ecdysozoa (Figure 7A; Bourlat et al. 2008). This clade contains organisms that shed a cuticle by molting (or ecdysis) (Bourlat et al. 2008). Therefore, C. elegans are more related to Drosophila and other insects than to mollusks, earthworms, or humans. The Caenorhabditis genus is included in the order Rhabditida, itself part of the larger subclass Chromadoria (De Ley 2006). While all known Caenorhabditis species are free-living, the Rhabditidae include animal and plant parasites, as well as free-living species that exist in a variety of terrestrial and aquatic ecosystems (Kiontke and Fitch 2005). As the ecology of Caenorhabditis is increasingly better understood, more species have been identified (Figure 7B; Félix et al. 2014). C. elegans has served as a rich starting place for 
comparative evolutionary studies among species. For example, developmental biologists use related nematode species to explore the changes in regulatory pathways and organogenesis that occur during evolution (Sommer 2005)and the frequent independent evolution of hermaphroditism (Figure 7B; Baldi et al. 2009).

A

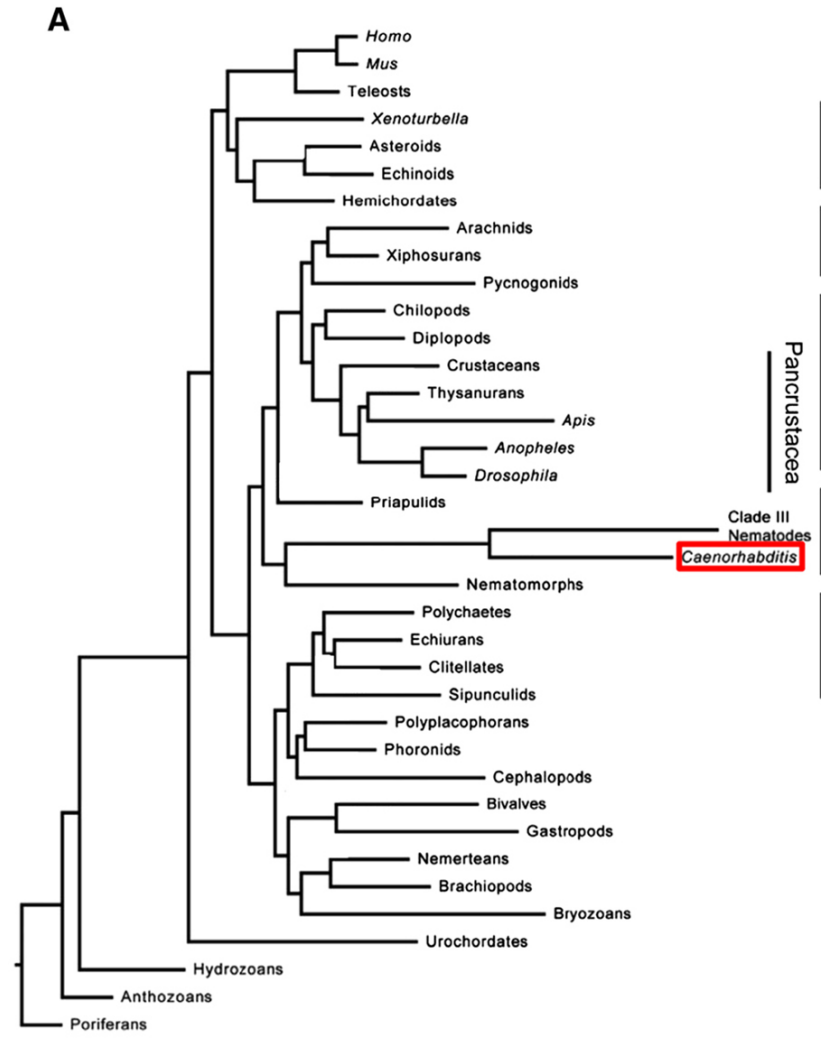

B

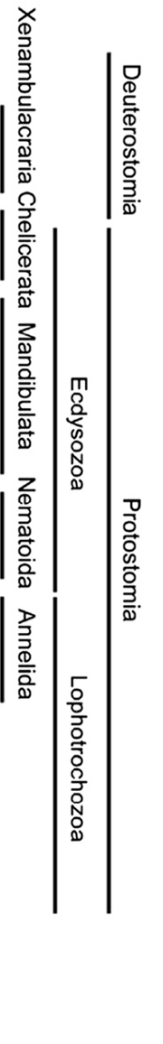

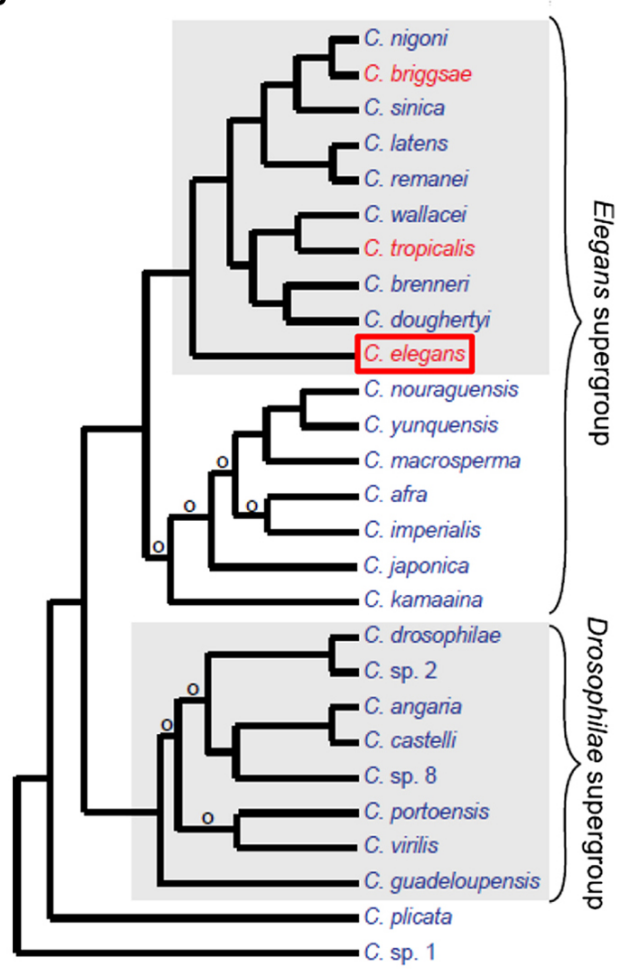

Figure 7. Caenorhabditis species in the animal kingdom. (A) Phylogenetic tree placing Caenorhabditis species (boxed in red) among metazoans based on sequence data from 2 ribosomal subunits, eight protein coding genes, and mitochondrial genomes. Image modified from Bourlat et al. (2008). (B) Phylogenetic tree placing C. elegans (boxed in red) among named Caenorhabditis species grown in the laboratory. Species in red have hermaphrodites and males; species in blue have females and males. An 'o' denotes branches with low support. Image modified from Félix et al. (2014).

The evolutionary relationship between $C$. elegans and parasitic nematode species has prompted research questions with direct human health relevance. Nematode parasites of humans cause major health problems, especially in less-developed nations. These parasites include hookworm and other soil-transmitted helminths that cause malnutrition and obstructive bowel disease, filarial nematodes such as Onchocerca volvulus, which causes river blindness, and Brugia malayi, which causes lymphatic filariasis (elephantiasis; Blaxter 1998). Plant parasitic nematodes cause significant crop damage (billions of dollars each year; Kandoth and Mitchum 2013)and animal parasites devastate domesticated animals (including heartworm in dogs and cats; McCall et al. 2008). C. elegans has played a critical role in elucidating the mode of action of anthelmintic drugs (Holden-Dye and Walker 2014). $C$. elegans may also prove useful in identifying new strategies to reduce or alleviate the action of parasitic nematodes, particularly since the emergence of resistance to current drugs (Holden-Dye and Walker 2014).

\section{Brief history of $C$. elegans research and key discoveries}

In Brenner's original vision, detailed elucidation of the development and anatomy of C. elegans would serve as the foundation for the subsequent analysis of mutants. Both of these efforts were completed primarily at the LMB. The transparency of the animal allowed John Sulston, Robert Horvitz, Judith Kimble, David Hirsh, and Einhard Schierenberg to describe every cell division starting with the single-celled zygote and ending with the adult male and hermaphrodite (Sulston and Horvitz 1977; Kimble and Hirsh 1979; Sulston et al. 1980; 1983). These efforts produced the first and only entire cell lineage of any multicellular organism. During this same time, John White, Sydney Brenner, Donna Albertson, Eileen Southgate, Sam Ward, and Nichol Thomson described the anatomy and connectivity of all 302 neurons of the adult hermaphrodite (Ward et al. 1975; Albertson and Thomson 1976; White et al. 1976; 1986). These projects set a standard for completeness in the understanding of the animal that has been a hallmark of $C$. elegans research. Such completeness was also seen in the sequencing of the $C$. elegans genome $(C$. 
elegans Genome Consortium, 1998), the description of the wiring diagram of the adult male (Jarrell et al. 2012), and development of genome-wide feeding RNAi experiments (Fraser et al. 2000; Kamath et al. 2001). Sydney Brenner, Robert Horvitz, and John Sulston were awarded the 2002 Nobel Prize in Physiology or Medicine in part for the significance of the lineage project as a platform for discovery of genes that orchestrated developmental decisions.

Since work on C. elegans genetics began in earnest during the 1970s, this animal has proven fruitful for making general discoveries about cell and developmental biology (Table 2). These findings have helped us understand molecular genetic mechanisms in all animals. Evolution has maintained thousands of conserved genes that play similar, or in some cases nearly identical, functions in nematodes and other animals including humans (Carroll et al. 2004). For example, the vertebrate apoptosis regulator Bcl-2 can functionally substitute for its $C$. elegans ortholog ced-9 (Hengartner and Horvitz 1994). Thus, discoveries with direct relevance to understanding all animals were made possible by what initially appeared to be an ambitious and esoteric undertaking to define in detail the structure and genetics of an apparently simple animal.

TABLE 2 Selected discoveries in C. elegans research

\begin{tabular}{|c|c|c|}
\hline Year & Discovery & References \\
\hline 1974 & $\begin{array}{l}\text { Identification of mutations that affect animal } \\
\text { behavior }\end{array}$ & Brenner 1974; Dusenberry et al. 1975; Hart 2006 \\
\hline 1975 & $\begin{array}{l}\text { First description of mutations that affect } \\
\text { thermotaxis and mechanotransduction }\end{array}$ & $\begin{array}{l}\text { Hedgecock and Russell 1975; Sulston } \text { et al. 1975; } \\
\text { Chalfie and Sulston 1981; Mori and Ohshima } \\
\text { 1995, }\end{array}$ \\
\hline 1977 & First cloning and sequencing of a myosin gene & Macleod et al. 1977 \\
\hline 1977 & $\begin{array}{l}\text { Genetic pathways for sex determination and } \\
\text { dosage compensation described }\end{array}$ & $\begin{array}{l}\text { Hodgkin and Brenner 1977; Meyer 2005; } \\
\text { Zarkower } 2006\end{array}$ \\
\hline 1981 & $\begin{array}{l}\text { Identification of mutations affecting touch } \\
\text { sensitivity }\end{array}$ & Sulston et al. 1975; Chalfie and Sulston 1981 \\
\hline 1981 & First germline stem cell niche identified & $\begin{array}{l}\text { Kimble and White 1981; Kimble and Crittenden } \\
2005\end{array}$ \\
\hline 1983 & $\begin{array}{l}\text { Notch signaling, presenilins, ternary complex, } \\
\text { and lateral inhibition roles in development } \\
\text { described }\end{array}$ & $\begin{array}{l}\text { Greenwald } \text { et al. 1983; Levitan and Greenwald } \\
\text { 1995; Petcherski and Kimble 2000; Greenwald } \\
\text { and Kovall } 2012\end{array}$ \\
\hline 1983 & First complete metazoan cell lineage & $\begin{array}{l}\text { Sulston and Horvitz 1977; Kimble and Hirsh } \\
\text { 1979; Sulston et al. } 1983\end{array}$ \\
\hline 1983 & Discovery of apoptosis (cell death) genes & $\begin{array}{l}\text { Hedgecock et al. 1983; Ellis and Horvitz 1986; } \\
\text { Yuan and Horvitz 1992; Yuan et al. 1993; } \\
\text { Conradt and Xue 2005 }\end{array}$ \\
\hline 1984 & Identification of heterochronic genes & $\begin{array}{l}\text { Ambros and Horvitz 1984; Slack and Ruvkun } \\
1997\end{array}$ \\
\hline 1986 & $\begin{array}{l}\text { First complete wiring diagram of a nervous } \\
\text { system }\end{array}$ & White et al. 1986; Jarrell et al. 2012; White 2013 \\
\hline 1987 & Discovery of the first axon guidance genes & Hedgecock et al. 1987, 1990; Culotti 1994 \\
\hline 1987 & $\begin{array}{l}\text { Identification of role of Notch signaling in } \\
\text { embryonic blastomeres }\end{array}$ & Priess et al. 1987; Priess 2005 \\
\hline 1988 & $\begin{array}{l}\text { Discovery of par genes, whose products affect the } \\
\text { asymmetric distribution of cellular components in } \\
\text { embryos }\end{array}$ & Kemphues et al. 1988; Gönczy and Rose 2005 \\
\hline 1988 & $\begin{array}{l}\text { Identification of the first LIM and POU } \\
\text { homeodomain transcription factors }\end{array}$ & $\begin{array}{l}\text { Way and Chalfie 1988; Finney et al. 1988; Hobert } \\
2013\end{array}$ \\
\hline 1990 & $\begin{array}{l}\text { First description of a role for RAS signaling } \\
\text { function in metazoan development }\end{array}$ & $\begin{array}{l}\text { Beitel et al. 1990; Han and Sternberg 1990; } \\
\text { Sternberg 2005; Sundaram } 2013\end{array}$ \\
\hline
\end{tabular}




\begin{tabular}{|c|c|c|}
\hline Year & Discovery & References \\
\hline 1993 & $\begin{array}{l}\text { Demonstration of a role for insulin pathway genes } \\
\text { in regulating lifespan }\end{array}$ & $\begin{array}{l}\text { Friedman and Johnson 1988; Kenyon et al. } 1993 \text {, } \\
\text { Kimura et al. 1997; Collins et al. } 2007\end{array}$ \\
\hline 1993 & $\begin{array}{l}\text { Identification of genes for conserved synaptic } \\
\text { functions }\end{array}$ & $\begin{array}{l}\text { Gengyo-Ando et al. 1993; Richmond et al. 1999; } \\
\text { Richmond } 2007\end{array}$ \\
\hline 1993 & $\begin{array}{l}\text { First microRNA (lin-4) and its mRNA target } \\
(\text { lin-14) described }\end{array}$ & $\begin{array}{l}\text { Lee } \text { et al. 1993; Wightman et al. } 1993 \text { Vella and } \\
\text { Slack } 2005\end{array}$ \\
\hline 1993 & Identification of nonsense-mediated decay genes & Pulak and Anderson 1993; Hodgkin 2005b \\
\hline 1994 & Introduction of GFP as a biological marker & Chalfie et al. 1994; Boulin et al. 2006 \\
\hline 1994 & $\begin{array}{l}\text { First demonstration of specific olfactory } \\
\text { receptor/ligand pair }\end{array}$ & Sengupta et al. 1994; Bargmann 2006 \\
\hline 1998 & First metazoan genome sequenced & $\begin{array}{l}\text { C. elegans Sequencing Consortium 1998; } \\
\text { Schwarz } 2005\end{array}$ \\
\hline 1998 & Discovery of RNA interference (RNAi) & Fire et al. 1998 \\
\hline 2000 & Conservation and ubiquity of miRNAs & Pasquinelli et al. 2000 \\
\hline 2000 & $\begin{array}{l}\text { Development of genome-wide RNAi } \\
\text { screening/first full genome-wide profiling of gene } \\
\text { function }\end{array}$ & Fraser et al. 2000; Kamath et al. 2001 \\
\hline 2000 & $\begin{array}{l}\text { Transgenerational inheritance and its mediation } \\
\text { by piRNA }\end{array}$ & Grishok et al. 2000; Ashe et al. 2012 \\
\hline 2002 & $\begin{array}{l}\text { First cytoplasmic polyA polymerase }(\mathrm{gld}-2) \\
\text { discovered }\end{array}$ & Wang et al. 2002; Kimble and Crittenden 2005 \\
\hline 2005 & $\begin{array}{l}\text { First full-genome RNAi profiling of early } \\
\text { embryogenesis }\end{array}$ & Sönnichsen et al. 2005 \\
\hline 2005 & $\begin{array}{l}\text { First use of channelrhodopsin optogenetics in an } \\
\text { intact animal }\end{array}$ & Nagel et al. 2005 \\
\hline 2011 & Discovery of first nematode viruses & Félix et al., 2011 \\
\hline
\end{tabular}

Genetic screens in C. elegans have yielded a number of first discoveries of genes and pathways that play important roles in all animals. These discoveries include key genes regulating apoptosis (programmed cell death) (Hedgecock et al. 1983; Ellis and Horvitz 1986), the Ras and Notch signaling pathways (Priess 2005; Greenwald and Kovall 2013; Sundaram 2013), synaptic function (Gengyo-Ando et al. 1993; Richmond et al. 1999), axon pathfinding (Hedgecock et al. 1987; 1990), longevity (Kenyon et al. 1993; Kimura et al. 1997), and developmental timing (the heterochronic genes) (Ambros and Horvitz 1984). The study of the heterochronic genes yielded the first small regulatory RNA, the microRNA (miRNA) product of the lin-4 gene (Lee et al. 1993). Robert Horvitz's 2002 Nobel Prize was awarded in part to recognize the broad significance of the genetic mechanisms of apoptosis, and Gary Ruvkun and Victor Ambros shared the 2008 Albert Lasker Award for Basic Medical Research in recognition of the general importance of miRNA.

C. elegans researchers also made important technical discoveries that were subsequently adapted and applied to other biological systems. For example, early gene-cloning efforts helped advance techniques for defining and assembling overlapping (contiguous) clones from animal genomes, which led to C. elegans being the first metazoan to have its entire genome sequenced in 1998 (C. elegans Genome Consortium, 1998). Some of these strategies were also employed in early human genome sequencing efforts. Another discovery that led to a novel technique with broad biological impact was gene silencing by RNA interference (RNAi) (Fire et al. 1998). This powerful technique allows researchers working with many organisms to silence the expression of any gene and earned Andrew Fire and Craig Mello the 2006 Nobel Prize in Physiology or Medicine (Fire 2007; Mello 2007). Finally, the development of green fluorescent protein (GFP) as a biological marker (Chalfie et al. 1994)for which Marty Chalfie shared the 2008 Nobel Prize in Chemistry grew directly from his interest in characterizing gene expression in live (and transparent) C. elegans. Now GFP and other fluorescent proteins are widely used biological tools. 


\section{The $C$. elegans community}

Having mentioned all the biological reasons that $C$. elegans provides outstanding opportunities to study biological questions and all the achievements that past studies have accomplished, we would be remiss if we did not mention one other reason why the field has flourished: the community of C. elegans researchers. Our field has had a long tradition of openness and sharing of reagents and ideas. This openness was first encouraged by the publication of the C. elegans newsletter, The Worm Breeder's Gazette. The Gazette was started by Bob Edgar at the University of California, Santa Cruz so C. elegans researchers could tell each other about their research. Often work was described in the Gazette many months before it was officially published. For example, the first description of GFP as a biological marker (in the October, 1993 issue of the Gazette) preceded the "official" publication by 5 months (Chalfie et al. 1994). The Gazette, now entirely online, is published as part of WormBook and is an excellent resource for new methods and helpful hints to aid C. elegans research.

The second person to greatly support and promote a community spirit among C. elegans researchers was John Sulston. When John began determining the physical map of the C. elegans genome with Alan Coulson, one of his goals was to promote sharing. He did this by not having any independent research of his own (taking away even a hint that he might be a competitor) and by providing a service whereby any researcher could get large amounts of DNA on either side of a cloned fragment or in the region of a mapped gene. As a result, researchers did not hoard their DNA before publication and investigators benefited by having clones of entire genes. The mapping project was able to link the physical (DNA) and genetic (recombination) maps. Consequently, several collaborations were initiated because scientists shared their data before publication (e.g., Savage et al. 1989; Miller et al. 1992). As the mapping project turned to the sequencing of the C. elegans genome, John made sure that the openness continued; results of the sequencing project were made available daily. This same approach was used when John and Alan along with Bob Waterston and many others turned to sequencing the human genome.

A field with many thousands of researchers cannot be as closely associated as in the early days when virtually all researchers knew one another because they were Sydney Brenner's F1s and F2 progeny. Nonetheless, the $C$. elegans field continues to share resources and information. The many free online resources (Table 1), the Caenorhabditis Genetics Center, and the many large, community projects (e.g., ModEncode Project, National Bioresource Project for the Experimental Animal C. elegans, and C. elegans Gene Knockout Consortium) show that the sharing spirit continues. This spirit and the general enthusiasm of $C$. elegans researchers are also evident at the biennial $C$. elegans and the many alternate-year special topics and local meetings. C. elegans has also proven a useful system for undergraduate and even high school education. The field continues to grow and to share.

Looking to the future, $C$. elegans will continue to be an important source of scientific discoveries. Many of the reasons for past successes will aid future research, especially the ability to look at individual cells within the context of the entire animal. Soon genome editing should generate loss-of-function alleles and transcriptionally and translationally-tagged reporters for every gene in the genome allowing structure/function studies of all the genes and their encoded products. In addition, analysis of the ever-increasing collection of regulatory RNAs certainly will add to our understanding of the development and adaptability of $C$. elegans. Continued use of optogenetics on larger and larger sets of neurons and the analysis of the functional expression of neurotransmitters, neuropeptides, and their receptors and of gap junction proteins is likely to produce the first integrated view of the working of a complete nervous system. Investigations using C. elegans promise to generate insights into new areas, such as host-pathogen interactions, synthetic biology, and ecology. Finally, we are confident that new and unexpected discoveries made in C. elegans, as they have done so often in the past, will change our views of how organisms develop, live, and age. We invite you to join us to be part of this exciting future.

\section{Acknowledgements}

We would like to thank the following individuals for helpful discussions and manuscript improvements: Oliver Hobert, Jonathan Hodgkin, Beth De Stasio, Eric Haag, Andy Golden, and members of the WormBook Editorial Board. We also thank Christopher Crocker and David Hall for the original illustration files that were modified in Figure 3. Research in M.C.'s laboratory is supported by National Institutes of Health (NIH) grant GM30997, in B.W.'s laboratory by NIH grant R15GM107799, and in A.K.C.'s laboratory by past grants from the National Institute of Dental and Craniofacial Research at NIH. 


\section{Literature cited}

Ahringer, J., 2006 Reverse genetics (April 6, 2006), WormBook, ed. The C. elegans Research Community, WormBook, doi/10.1895/wormbook.1.47.1, http://www.wormbook.org.

Albertson, D. G., and J. N. Thomson, 1976 The pharynx of Caenorhabditis elegans. Philos Trans R Soc Lond B Biol Sci. 275: 299-325. Abstract Article

Altun, Z. F., L. A. Herndon, C. Crocker, R. Lints, and D. H. Hall (eds), 2002-2015 WormAtlas. Available at: http://www.wormatlas.org.

Ambros, V. and H. R. Horvitz, 1984 Heterochronic mutants of the nematode Caenorhabditis elegans. Science 226: 409-416. Abstract Article

Ardiel, E. L. and C. H. Rankin, 2010 An elegant mind: learning and memory in Caenorhabditis elegans. Learn. Mem. 17: 191-201. Abstract Article

Ashe, A., A. Sapetschnig, E. M. Weick, J. Mitchell, M. P. Bagijn et al., 2012 piRNAs can trigger a multigenerational epigenetic memory in the germline of C. elegans. Cell 150: 88-99. Abstract Article

Avery, L and H. R. Horvitz, 1989 Pharyngeal pumping continues after laser killing of the pharyngeal nervous system of C. elegans. Neuron 3: 473-485. Abstract Article

Avery, L. and Y. J. You, 2012 C. elegans feeding (May 21, 2012), WormBook, ed. The C. elegans Research Community, WormBook, doi/10.1895/wormbook.1.150.1, http://www.wormbook.org. Abstract Article

Avery, L. and B. B. Shtonda, 2003 Food transport in the C. elegans pharynx. J. Exp. Biol. 206: 2441-2457. Abstract Article

Baldi, C., S. Cho, and R. E. Ellis, 2009 Mutations in two independent pathways are sufficient to create hermaphroditic nematodes. Science 326: 1002-1005. Abstract Article

Balla, K. M. and E. R. Troemel, 2013 Caenorhabditis elegans as a model for intracellular pathogen infection. Cell. Microbiol. 15: 1313-1322. Abstract Article

Bargmann, C. I., 1998 Neurobiology of the Caenorhabditis elegans genome. Science 282: 2028-2033. Abstract Article

Bargmann, C. I. and H. R. Horvitz, 1991 Control of larval development by chemosensory neurons in Caenorhabditis elegans. Science 251: 1243-1246. Abstract Article

Bargmann, C. I., 2006 Chemosensation in C. elegans (October 25, 2006), WormBook, ed. The C. elegans Research Community, WormBook, doi/10.1895/wormbook.1.123.1, http://www.wormbook.org. Abstract Article

Barr, M. M. and L. R. Garcia, 2006 Male mating behavior (June 19, 2006), WormBook, ed. The C. elegans Research Community, WormBook, doi/10.1895/wormbook.1.78.1, http://www.wormbook.org. Abstract Article

Barrière A. and M. A. Félix, 2014 Isolation of C. elegans and related nematodes. WormBook ed. The C. elegans Research Community, WormBook, 1-19. doi: 10.1895/wormbook.1.115.2, http://www.wormbook.org. Abstract Article

Beitel, G. J., S. G. Clark, and H. R. Horvitz., 1990 Caenorhabditis elegans ras gene let-60 acts as a switch in the pathway of vulval induction. Nature 348: 503-509. Abstract Article

Benian, G. M. and H. F. Epstein, 2011 Caenorhabditis elegans muscle: a genetic and molecular model for protein interactions in the heart. Circ. Res. 109: 1082-1095. Abstract Article 
Blaxter, M., D. R. Denver, 2012 The worm in the world and the world in the worm. BMC Biol. 10: 57. Abstract Article

Blaxter, M., 1998 Caenorhabditis elegans is a nematode. Science 282: 2041-2046. Abstract Article

Blumenthal, T., 2005 Trans-splicing and operons (June 25, 2005), WormBook, ed. The C. elegans Research Community, WormBook, doi/10.1895/wormbook.1.5.1, http://www.wormbook.org. Abstract Article

Boulin, T., J. F. Etchberger, O. Hobert, 2006 Reporter gene fusions (April 5, 2006), WormBook, ed. The C. elegans Research Community, WormBook, doi/10.1895/wormbook.1.106.1, http://www.wormbook.org. Abstract Article

Bourlat, S. J., C. Nielsen, A. D. Economou, and M. J. Telford, 2008 Testing the new animal phylogeny: a phylum level molecular analysis of the animal kingdom. Mol. Phylogenet. Evol. 49: 23-31. Abstract Article

Brenner, S., 1974 The genetics of Caenorhabditis elegans. Genetics 77: 71-94. Abstract Article

Brenner, S., 1988 Foreword. The Nematode Caenorhabditis elegans, edited by W. B. Wood, Cold Spring Harbor Laboratory Press, Cold Spring Harbor, NY.

Brenner, S., 2002 The worm's turn. Curr. Biol. 12: R713. Abstract Article

Bürglin, T. R. and P. E. Kuwabara, 2006 Homologs of the Hh signalling network in C. elegans. (January 28, 2006), WormBook, ed. The C. elegans Research Community, WormBook, doi/10.1895/wormbook.1.76.1, http://www.wormbook.org. Abstract Article

C. elegans Sequencing Consortium, 1998 Genome sequence of the nematode C. elegans: a platform for investigating biology. Science 282: 2012-2018. Abstract Article

Carlsson, P. and M. Mahlapuu, 2002 Forkhead transcription factors: key players in development and metabolism. Dev. Biol. 250: 1-23. Abstract Article

Carroll, S. B., J. K. Grenier, and S. D. Weatherbee, 2004 From DNA to Diversity: Molecular Genetics and the Evolution of Animal Design, 2nd edition, Wiley-Blackwell, Hoboken, NJ. Abstract

Chalfie, M. and J. Sulston, 1981 Developmental genetics of the mechanosensory neurons of Caenorhabditis elegans. Dev. Biol. 82: 358-370. Abstract Article

Chalfie, M., J. E. Sulston, J. G. White, E. Southgate, J. N. Thomson et al., 1985 The neural circuit for touch sensitivity in Caenorhabditis elegans. J. Neurosci. 5: 956-964 Abstract Article

Chalfie, M., Y. Tu, G. Euskirchen, W. W. Ward, and D. C. Prasher, 1994 Green fluorescent protein as a marker for gene expression. Science 263: 802-805. Abstract Article

Chamberlain, J. S. and G. M. Benian, 2000 Muscular dystrophy: the worm turns to genetic disease. Curr. Biol. 10: R795-R797. Abstract Article

Chisholm, A. D. and J. Hardin, 2005 Epidermal morphogenesis (December 01, 2005), WormBook, ed. The C. elegans Research Community, WormBook, doi/10.1895/wormbook.1.35.1, http://www.wormbook.org. Abstract Article

Coghlan, A., 2005 Nematode genome evolution (September 07, 2005), WormBook, ed. The C. elegans Research Community, WormBook, doi/10.1895/wormbook.1.15.1, http://www.wormbook.org. Abstract Article

Collins, J. J., C. Huang, S. Hughes, and K. Kornfeld, 2007 The measurement and analysis of age-related changes in Caenorhabditis elegans (December 7, 2007), WormBook, ed. The C. elegans Research Community, WormBook, doi/10.1895/wormbook.1.137.1, http://www.wormbook.org. Abstract Article

Conradt, B. and D. Xue, 2005 Programmed cell death (October 06, 2005), WormBook, ed. The C. elegans Research Community, WormBook, doi/10.1895/wormbook.1.32.1, http://www.wormbook.org. Abstract Article 
Cook, A., C. J. Franks, and L. Holden-Dye, 2006 Electrophysiological recordings from the pharynx (May 17, 2006), WormBook, ed. The C. elegans Research Community, WormBook, doi/10.1895/wormbook.1.110.1, http://www.wormbook.org. Abstract Article

Corsi A.K., Wightman B., and Chalfie M. 2015 A Transparent window into biology: A primer on Caenorhabditis elegans. GENETICS 200: 387-407. Abstract Article

Croll, N. A. and B. E. Matthews, 1977 Biology of Nematodes, Blackie and Son, Glasgow, London.

Culetto, E. and D. B. Sattelle. 2000 A role for Caenorhabditis elegans in understanding the function and interactions of human disease genes. Hum. Mol. Genet. 9: 869-877. Abstract Article

Culotti, J.G., 1994 Axon guidance mechanisms in Caenorhabditis elegans. Curr. Opin. Genet. Dev. 4: 587-595. Abstract Article

Darby, B. J. and M. A. Herman, 2014 Effect of prey richness on a consumer's intrinsic growth rate. Oecologia 175: 243-250. Abstract Article

Darby, C., 2005 Interactions with microbial pathogens (September 6, 2005), WormBook, ed. The C. elegans Research Community, WormBook, doi/10.1895/wormbook.1.21.1, http://www.wormbook.org. Abstract Article

De, Ley, P., 2006 A quick tour of nematode diversity and the backbone of nematode phylogeny (January 25, 2006), WormBook, ed. The C. elegans Research Community, WormBook, doi/10.1895/wormbook.1.41.1, http://www.wormbook.org. Abstract Article

Diogo, J. and A. Bratanich, 2014 The nematode Caenorhabditis elegans as a model to study viruses. Arch. Virol. 159: 2843-2851. Abstract Article

Doitsidou, M., R. J. Poole, S. Sarin, H. Bigelow, O. Hobert, 2010 C. elegans mutant identification with a one-step whole-genome-sequencing and SNP mapping strategy. PLoS ONE 5: e15435. Abstract Article

Dong, X., O. W. Liu, A. S. Howell, and K. Shen, 2013 An extracellular adhesion molecule complex patterns dendritic branching and morphogenesis. Cell 155: 296-307. Abstract Article

Driscoll, M. and M. Chalfie, 1992 Developmental and abnormal cell death in C. elegans. Trends Neurosci. 15: 15-19. Abstract Article

Dusenbery, D. B., R. E. Sheridan, and R. L. Russell, 1975 Chemotaxis-defective mutants of the nematode Caenorhabditis elegans. Genetics 80: 297-309. Abstract Article

Ellis, H. M., and H. R. Horvitz, 1986 Genetic control of programmed cell death in the nematode C. elegans. Cell 44: 817-829. Abstract Article

Emmons, S. W., 2005 Male development (November 10, 2005), WormBook, ed. The C. elegans Research Community, WormBook, doi/10.1895/wormbook.1.33.1, http://www.wormbook.org. Abstract Article

Evans, T. C., 2006 Transformation and microinjection (April 6, 2006), WormBook, ed. The C. elegans Research Community, WormBook, doi/10.1895/wormbook.1.108.1, http://www.wormbook.org. Abstract Article

Feinberg, E. H., M. K. Vanhoven, A. Bendesky, G. Wang, R. D. Fetter et al., 2008 GFP Reconstitution Across Synaptic Partners (GRASP) defines cell contacts and synapses in living nervous systems. Neuron 57: 353-363. Abstract Article

Félix, M.A., 2008 RNA interference in nematodes and the chance that favored Sydney Brenner. J. Biol. 7: 34. Abstract Article

Félix M.A., F. Duveau, 2012 Population dynamics and habitat sharing of natural populations of Caenorhabditis elegans and C. briggsae. BMC Biol. 10: 59. Abstract Article 
Félix M. A., A. Ashe, J. Piffaretti, G. Wu, I. Nuez et al., 2011 Natural and experimental infection of Caenorhabditis nematodes by novel viruses related to nodaviruses. PLoS Biol. 9: e1000586. Abstract Article

Félix M. A., C. Braendle, and A. D. Cutter, 2014 A streamlined system for species diagnosis in Caenorhabditis (Nematoda: Rhabditidae) with name designations for 15 distinct biological species. PLoS ONE 9: e94723. Abstract Article

Finney, M., G. Ruvkun, H. R. Horvitz, 1988 The $C$. elegans cell lineage and differentiation gene unc-86 encodes a protein with a homeodomain and extended similarity to transcription factors. Cell 55: 757-769. Abstract Article

Fire, A., S. Xu, M. K. Montgomery, S. A. Kostas, S. E. Driver, and C. C. Mello, 1998 Potent and specific genetic interference by double-stranded RNA in Caenorhabditis elegans. Nature 391: 806-811. Abstract Article

Fire, A. Z., 2007 Gene silencing by double-stranded RNA (Nobel Lecture). Angew. Chem. Int. Ed. Engl. 46: 6966-6984. Abstract Article

Forrester, W. C. and G. Garriga, 1997 Genes necessary for C. elegans cell and growth cone migrations. Development 124: 1831-1843. Abstract

Fraser, A. G., R. S. Kamath, P. Zipperlen, M. Martinez-Campos, M. Sohrmann et al., 2000 Functional genomic analysis of $C$. elegans chromosome I by systematic RNA interference. Nature 408: 325-330. Abstract Article

Friedman, D. B. and T. E. Johnson, 1988 A mutation in the age-1 gene in Caenorhabditis elegans lengthens life and reduces hermaphrodite fertility. Genetics 118: 75-86. Abstract

Frøkjær-Jensen, C., 2013 Exciting prospects for precise engineering of Caenorhabditis elegans genomes with CRISPR/Cas9. Genetics 195: 635-642. Abstract

Gengyo-Ando K., Y. Kamiya, A. Yamakawa, K. Kodaira, K. Nishiwaki et al., 1993 The C. elegans unc-18 gene encodes a protein expressed in motor neurons. Neuron 11: 703-711. Abstract Article

Golden, J. W. and D. L. Riddle 1984 The Caenorhabditis elegans dauer larva: developmental effects of pheromone, food, and temperature. Dev. Biol. 102: 368-378. Abstract Article

Gönczy, P. and L. S. Rose, 2005 Asymmetric cell division and axis formation in the embryo (October 15, 2005), WormBook, ed. The C. elegans Research Community, WormBook, doi/10.1895/wormbook.1.30.1, http://www.wormbook.org. Abstract Article

Goodman, M. B, D. H. Hall, L. Avery, and S. R. Lockery, 1998 Active currents regulate sensitivity and dynamic range in C. elegans neurons. Neuron 20: 763-772. Abstract Article

Grant, B. D. and M. Sato, 2006 Intracellular trafficking (January 21, 2006), WormBook, ed. The C. elegans Research Community, WormBook, doi/10.1895/wormbook.1.77.1, http://www.wormbook.org. Abstract

Greenwald, I. and R. Kovall, 2013 Notch signaling: genetics and structure (January 17, 2013), WormBook, ed. The C. elegans Research Community, WormBook, doi/10.1895/wormbook.1.10.2, http://www.wormbook.org. Abstract Article

Greenwald, I., 1985 lin-12, a nematode homeotic gene, is homologous to a set of mammalian proteins that includes epidermal growth factor. Cell 43: 583-590. Abstract Article

Greenwald, I. S., P. W. Sternberg, and H. R. Horvitz, 1983 The lin-12 locus specifies cell fates in Caenorhabditis elegans. Cell 34: 435-344. Abstract Article

Grishok, A., H. Tabara, and C. C. Mello, 2000 Genetic requirements for inheritance of RNAi in C. elegans. Science 287: 2494-2497. Abstract Article

Hammarlund, M. and Y. Jin, 2014 Axon regeneration in C. elegans. Curr. Opin .Neurobiol. 27: 199-207. Abstract Article 
Han, M. and P. W. Sternberg, 1990 let-60, a gene that specifies cell fates during C. elegans vulval induction, encodes a ras protein. Cell 63: 921-931. Abstract Article

Hart, A.C., 2006 Behavior (July 3, 2006), WormBook, ed. The C. elegans Research Community, WormBook, doi/10.1895/wormbook.1.87.1, http://www.wormbook.org. Article

Hedgecock, E. M. and R. L. Russell, 1975 Normal and mutant thermotaxis in the nematode Caenorhabditis elegans. Proc. Natl. Acad. Sci. USA. 72: 4061-4065. Abstract Article

Hedgecock, E. M and J. G. White, 1985 Polyploid tissues in the nematode Caenorhabditis elegans. Dev. Biol. 107: 128-133. Abstract Article

Hedgecock, E. M., J. E. Sulston, and J. N. Thomson, 1983 Mutations affecting programmed cell deaths in the nematode Caenorhabditis elegans. Science 220: 1277-1279. Abstract Article

Hedgecock, E. M., J. G. Culotti, D. H. Hall, and B. D. Stern, 1987 Genetics of cell and axon migrations in Caenorhabditis elegans. Development 100: 365-382. Abstract Article

Hedgecock, E. M., J. G. Culotti, and D. H. Hall, 1990 The unc-5, unc-6, and unc-40 genes guide circumferential migrations of pioneer axons and mesodermal cells on the epidermis in C. elegans. Neuron 4: 61-85. Abstract Article

Hengartner, M. O., and H. R. Horvitz, 1994 C. elegans cell survival gene ced-9 encodes a functional homolog of the mammalian proto-oncogene $b c l-2$. Cell 76: 665-676. Abstract Article

Herman, M. A., 2006 Hermaphrodite cell-fate specification (January 09, 2006), WormBook, ed. The C. elegans Research Community, WormBook, doi/10.1895/wormbook.1.39.1, http://www.wormbook.org. Abstract Article

Hobert, O., 2010 Neurogenesis in the nematode Caenorhabditis elegans (October 4, 2010), WormBook, ed. The C. elegans Research Community, WormBook, doi/10.1895/wormbook.1.12.2, http://www.wormbook.org. Abstract Article

Hobert, O., 2013 The neuronal genome of Caenorhabditis elegans (August 13, 2013), WormBook, ed. The C. elegans Research Community, WormBook, doi/10.1895/wormbook.1.161.1, http://www.wormbook.org. Abstract Article

Hodgkin, J., 1983 Male phenotypes and mating efficiency in Caenorhabditis elegans. Genetics 103: 43-64. Abstract Article

Hodgkin, J., 2005 Genetic suppression (December 27, 2005b), WormBook, ed. The C. elegans Research Community, WormBook, doi/10.1895/wormbook.1.59.1, http://www.wormbook.org. Abstract Article

Hodgkin, J. A., and S. Brenner, 1977 Mutations causing transformation of sexual phenotype in the nematode Caenorhabditis elegans. Genetics 86: 275-287. Abstract Article

Holden-Dye, L. and R. J. Walker, 2014 Anthelmintic drugs and nematicides: studies in Caenorhabditis elegans (December 16, 2014), WormBook, ed. The C. elegans Research Community, WormBook, doi/10.1895/wormbook.1.143.2, http://www.wormbook.org. Abstract Article

Hu, C. W., J. L. Chen, Y. W. Hsu, C. C. Yen, and M. R. Chao, 2015 Trace analysis of methylated and hydroxymethylated cytosines in DNA by isotope-dilution LC-MS/MS: first evidence of DNA methylation in Caenorhabditis elegans. Biochem. J. 465: 39-47. Abstract Article

Hu, P.J., 2007 Dauer (August 08, 2007), WormBook, ed. The C. elegans Research Community, WormBook, doi/10.1895/wormbook.1.144.1, http://www.wormbook.org. Abstract Article

Hubbard, E. J. A. and D. Greenstein, 2005 Introduction to the germ line (September 1, 2005), WormBook, ed. The C. elegans Research Community, WormBook, doi/10.1895/wormbook.1.18.1, http://www.wormbook.org. Abstract Article 
Husson, S. J., A. Gottschalk, and A. M. Leifer, 2013 Optogenetic manipulation of neural activity in C. elegans: from synapse to circuits and behaviour. Biol. Cell 105: 235-250. Abstract Article

Jarrell, T. A., Y. Wang, A. E. Bloniarz, C. A. Brittin, M. Xu et al., 2012 The connectome of a decision-making neural network. Science 337: 437-444. Abstract Article

Jorgensen, E. M. and S. E. Mango, 2002 The art and design of genetic screens: Caenorhabditis elegans. Nat. Rev. Genet. 3: 356-369. Abstract Article

Kaletta, T. and M. O. Hengartner, 2006 Finding function in novel targets: C. elegans as a model organism. Nat. Rev. Drug Discov. 5: 387-398. Abstract Article

Kamath, R. S., M. Martinez-Campos, P. Zipperlen, A. G. Fraser, and J. Ahringer, 2001 Effectiveness of specific RNA-mediated interference through ingested double-stranded RNA in Caenorhabditis elegans. Genome Biol. 2: RESEARCH0002. Abstract Article

Kandoth, P. K. and M. G. Mitchum. 2013 War of the worms: how plants fight underground attacks. Curr. Opin. Plant Biol. 16: 457-463. Abstract Article

Kemphues, K. J., J. R. Priess, D. G. Morton, and N. S. Cheng, 1988 Identification of genes required for cytoplasmic localization in early C. elegans embryos. Cell 52: 311-320. Abstract Article

Kennedy, M. W., 2013 Ascaris - Antigens, allergens, immunogenetics, protein structures, pp. 51-79 in Ascaris, The Neglected Parasite, Ed. 100, Chap. 3. Elsevier, Holland.

Kenyon, C., J. Chang, E. Gensch, A. Rudner, and R. Tabtiang, 1993 A C. elegans mutant that lives twice as long as wild type. Nature 366: 461-464. Abstract Article

Kerr, R., V. Lev-Ram, G. Baird, P. Vincent, R. Y. Tsien, and W. R. Schafer, 2000 Optical imaging of calcium transients in neurons and pharyngeal muscle of $C$. elegans. Neuron 26: 583-594. Abstract Article

Kerr, R.A., 2006 Imaging the activity of neurons and muscles (June 2, 2006), WormBook, ed. The C. elegans Research Community, WormBook, doi/10.1895/wormbook.1.113.1, http://www.wormbook.org. Abstract Article

Kimble, J. and D. Hirsh, 1979 The post-embryonic cell lineages of the hermaphrodite and male gonads in Caenorhabditis elegans. Dev. Biol. 70: 396-417. Abstract Article

Kimble, J. E. and J. G. White, 1981 On the control of germ cell development in Caenorhabditis elegans. Dev. Biol. 81: 208-219. Abstract Article

Kimble, J. and S. L. Crittenden, 2005 Germline proliferation and its control (August 15, 2005), WormBook, ed. The C. elegans Research Community, WormBook, doi/10.1895/wormbook.1.13.1, http://www.wormbook.org. Abstract Article

Kimura, K. D., H. A. Tissenbaum, Y. Liu, G. Ruvkun, 1997 daf-2, an insulin receptor-like gene that regulates longevity and diapause in Caenorhabditis elegans. Science 277: 942-946. Abstract Article

Kiontke, K. and D. H. A. Fitch, 2005 The Phylogenetic relationships of Caenorhabditis and other rhabditids (August 11, 2005), WormBook, ed. The C. elegans Research Community, WormBook, doi/10.1895/wormbook.1.11.1, http://www.wormbook.org. Abstract Article

Kiontke, K. and W. Sudhaus, 2006 Ecology of Caenorhabditis species (January 09, 2006), WormBook, ed. The $C$. elegans Research Community, WormBook, doi/10.1895/wormbook.1.37.1, http://www.wormbook.org. Abstract Article

Kutscher, L. M. and S. Shaham, Forward and reverse mutagenesis in C. elegans (January 17, 2014), WormBook, ed. The C. elegans Research Community, WormBook, doi/10.1895/wormbook.1.167.1, http://www.wormbook.org. Abstract Article 
Lee, H., M. K. Choi, D. Lee, H. S. Kim, H. Hwang et al., 2011 Nictation, a dispersal behavior of the nematode Caenorhabditis elegans, is regulated by IL2 neurons. Nat. Neurosci. 15: 107-112. Abstract Article

Lee, R. C., R. L. Feinbaum, and V. Ambros, 1993 The C. elegans heterochronic gene lin-4 encodes small RNAs with antisense complementarity to lin-14. Cell 75: 843-854. Abstract Article

Lesa, G.M., 2006 Isolation of Caenorhabditis elegans gene knockouts by PCR screening of chemically mutagenized libraries. Nat. Protoc. 1, 2231-2240. Abstract Article

Levitan, D. and I. Greenwald, 1995 Facilitation of lin-12-mediated signalling by sel-12, a Caenorhabditis elegans S182 Alzheimer's disease gene. Nature 377: 351-354. Abstract Article

Li, C. and K. Kim, 2008 Neuropeptides (September 25, 2008), WormBook, ed. The C. elegans Research Community, WormBook, doi/10.1895/wormbook.1.142.1, http://www.wormbook.org. Abstract Article

Lockery, S., 2007 Channeling the worm: microfluidic devices for nematode neurobiology. Nat. Methods. 4: 691-692. Abstract Article

Lockery, S.R., and M.B. Goodman, 1998 Tight-seal whole-cell patch clamping of Caenorhabditis elegans neurons. Methods Enzymol. 293: 201-217. Abstract Article

Lockery, S. R., and M. B. Goodman, 2009 The quest for action potentials in C. elegans neurons hits a plateau. Nat. Neurosci. 12: 377-378. Abstract Article

MacLeod, A. R., R. H. Waterston, R. M. Fishpool, and S. Brenner, 1977 Identification of the structural gene for a myosin heavy-chain in Caenorhabditis elegans. J. Mol. Biol. 114: 133-140. Abstract Article

MacLeod, A. R., J. Karn, and S. Brenner, 1981 Molecular analysis of the unc-54 myosin heavy-chain gene of Caenorhabditis elegans. Nature 291: 386-390. Abstract Article

Mango, S.E., 2007 The C. elegans pharynx: a model for organogenesis (January 22, 2007), WormBook, ed. The $C$. elegans Research Community, WormBook, doi/10.1895/wormbook.1.129.1, http://www.wormbook.org. Abstract Article

Mango, S. E., E. J. Lambie, and J. Kimble, 1994 The pha-4 gene is required to generate the pharyngeal primordium of Caenorhabditis elegans. Development 120: 3019-3031. Abstract Article

McCall, J.W., C. Genchi, L.H. Kramer, J. Guerrero, and L. Venco, 2008 Heartworm disease in animals and humans. Adv. Parasitol. 66: 193-285. Abstract Article

McGhee, J. D., 2007 The C. elegans intestine (March 27, 2007), WormBook, ed. The C. elegans Research Community, WormBook, doi/10.1895/wormbook.1.133.1, http://www.wormbook.org. Abstract Article

Mello, C. C., 2007 Return to the RNAi world: rethinking gene expression and evolution (Nobel Lecture). Angew. Chem. Int. Ed. Engl. 46: 6985-6994. Abstract Article

Mello, C. C. and A. Fire, 1995 DNA Transformation, pp. 452-482 in Caenorhabditis elegans: Modern Biological Analysis of an Organism, edited by H. F. Epstein, and D. C. Shakes. Academic Press, San Diego.

Merritt, C., C. M. Gallo, D. Rasoloson, and G. Seydoux, 2010 Transgenic solutions for the germline (February 8, 2010), WormBook, ed. The C. elegans Research Community, WormBook, doi/10.1895/wormbook.1.148.1, http://www.wormbook.org. Abstract Article

Meyer, B. J. X-Chromosome dosage compensation (June 25, 2005), WormBook, ed. The C. elegans Research Community, WormBook, doi/10.1895/wormbook.1.8.1, http://www.wormbook.org. Abstract Article

Miller, D. M., M. M. Shen, C. E. Shamu, T. R. Bürglin, G. Ruvkun et al., 1992 C. elegans unc-4 gene encodes a homeodomain protein that determines the pattern of synaptic input to specific motor neurons. Nature 355: 841-845. Abstract Article 
Minevich, G., D.S. Park, D. Blankenberg, R.J. Poole, and O. Hobert 2012 CloudMap: a cloud-based pipeline for analysis of mutant genome sequences. Genetics 192: 1249-1269. Abstract Article

Moerman, D. G., and A. Fire, 1997 Muscle: Structure, function and development, pp. 417-470 in C. elegans II, edited by D.L. Riddle, T. Blumenthal, B.J. Meyer, and J.R. Priess. Cold Spring Harbor Press, Cold Spring Harbor, NY.

Moerman, D. G. and B.D. Williams, 2006 Sarcomere assembly in C. elegans muscle (January 16, 2006). WormBook, ed. The C. elegans Research Community, WormBook, doi/10.1895/wormbook.1.81.1, http://www.wormbook.org. Abstract Article

Mori, I. and Y. Ohshima, 1995 Neural regulation of thermotaxis in Caenorhabditis elegans. Nature 376: $344-348$. Abstract Article

Nagel, G., M. Brauner, J .F. Liewald, N. Adeishvili, E. Bamberg et al., 2005 Light activation of channelrhodopsin-2 in excitable cells of Caenorhabditis elegans triggers rapid behavioral responses. Curr. Biol. 15: 2279-2284. Abstract Article

Oikonomou, G., and S. Shaham, 2011 The glia of Caenorhabditis elegans. Glia 59: 1253-1263. Abstract Article

Page, A.P. and I.L. Johnstone, 2007 The cuticle (March 19, 2007), WormBook, ed. The C. elegans Research Community, WormBook, doi/10.1895/wormbook.1.138.1, http://www.wormbook.org. Abstract Article

Pasquinelli, A. E., B. J. Reinhart, F. Slack, M. Q. Martindale, M. I. Kuroda et al., 2000 Conservation of the sequence and temporal expression of let-7 heterochronic regulatory RNA. Nature 408: 86-89. Abstract Article

Petcherski, A. G. and J. Kimble, 2000 LAG-3 is a putative transcriptional activator in the C. elegans Notch pathway. Nature 405: 364-368. Abstract Article

Podbilewicz, B., 2006 Cell fusion (January 06, 2006), WormBook, ed. The C. elegans Research Community, WormBook, doi/10.1895/wormbook.1.52.1, http://www.wormbook.org. Abstract Article

Priess, J., 2005 Notch signaling in the C. elegans embryo (June 25, 2005), WormBook, ed. The C. elegans Research Community, WormBook, doi/10.1895/wormbook.1.4.1, http://www.wormbook.org. Abstract Article

Priess, J. R., H. Schnabel, and R. Schnabel, 1987 The glp-1 locus and cellular interactions in early C. elegans embryos. Cell 51: 601-611. Abstract Article

Pulak, R. and P. Anderson, 1993 mRNA surveillance by the Caenorhabditis elegans smg genes. Genes Dev. 7: 1885-1897. Abstract Article

Raizen, D. M. and L. Avery, 1994 Electrical activity and behavior in the pharynx of Caenorhabditis elegans. Neuron 12: 483-495. Abstract Article

Raizen, D. M., J. E. Zimmerman, M. H. Maycock, U. D. Ta, Y. J. You et al., 2008 Lethargus is a Caenorhabditis elegans sleep-like state. Nature 451: 569-572. (Erratum in: Nature, 2008, 453: 952) Abstract Article

Rao, A. U., L. K. Carta, E. Lesuisse, and I. Hamza, 2005 Lack of heme synthesis in a free-living eukaryote. Proc. Natl. Acad. Sci. USA, 102: 4270-4275. Abstract Article

Rechavi, O., L. Houri-Ze'evi, S. Anava, W. S. Goh, S. Y. Kerk et al., 2014 Starvation-induced transgenerational inheritance of small RNAs in C. elegans. Cell 158: 277-287. Abstract Article

Richmond, J. E., Davis W. S., E. M. Jorgensen, 1999 UNC-13 is required for synaptic vesicle fusion in C. elegans. Nat. Neurosci. 2: 959-964. Abstract Article

Richmond, J., 2007 Synaptic function (December 7, 2007), WormBook, ed. The C. elegans Research Community, WormBook, doi/10.1895/wormbook.1.69.1, http:/www.wormbook.org. Abstract Article 
Richmond, J. E., 2006 Electrophysiological recordings from the neuromuscular junction of C. elegans (October 6, 2006), WormBook, ed. The C. elegans Research Community, WormBook, doi/10.1895/wormbook.1.112.1, http://www.wormbook.org. Abstract Article

Ruvkun, G. and O. Hobert, 1998 The taxonomy of developmental control in Caenorhabditis elegans. Science 282: 2033-2041. Abstract Article

Salkoff, L., A. D. Wei, B. Baban, A. Butler, G. Fawcett et al., 2005 Potassium channels in C. elegans (December 30, 2005), WormBook, ed. The C. elegans Research Community, WormBook, doi/10.1895/wormbook.1.42.1, http://www.wormbook.org. Abstract Article

San-Miguel A. and H. Lu, 2013 Microfluidics as a tool for C. elegans research. (September 24, 2013), WormBook, ed. The C. elegans Research Community, WormBook, doi/10.1895/wormbook.1.162.1, http://www.wormbook.org. Abstract Article

Savage, C., M. Hamelin, J. G. Culotti, A. Coulson, D. G. Albertson et al., 1989 mec-7 is a beta-tubulin gene required for the production of 15-protofilament microtubules in Caenorhabditis elegans. Genes Dev. 3: 870-881. Abstract Article

Schafer, W.R., 2005 Deciphering the neural and molecular mechanisms of C. elegans behavior. Curr. Biol. 15: R723-729. Abstract Article

Schwarz, E.M., 2005 Genomic classification of protein-coding gene families (September 23, 2005), WormBook, ed. The C. elegans Research Community, WormBook, doi/10.1895/wormbook.1.29.1, http://www.wormbook.org. Abstract Article

Schweinsberg, P.J. and B.D. Grant, 2013 C. elegans gene transformation by microparticle bombardment (December 30, 2013), WormBook, ed. The C. elegans Research Community, WormBook, doi/10.1895/wormbook.1.166.1, http://www.wormbook.org. Abstract Article

Sengupta, P., H. A. Colbert, C. I. Bargmann, 1994 The C. elegans gene odr-7 encodes an olfactory-specific member of the nuclear receptor superfamily. Cell 79: 971-980. Abstract Article

Shaham, S., 2015 Glial development and function in the nervous system of Caenorhabditis elegans. Cold Spring Harb. Perspect. 8: 7(4) Biol. 10.1101/cshperspect.a020578. Abstract Article

Shaye, D. D. and I. Greenwald, 2011 OrthoList: a compendium of C. elegans genes with human orthologs. PLoS ONE 6: e20085. Abstract Article

Silhankova, M. and H. C. Korswagen, 2007 Migration of neuronal cells along the anterior-posterior body axis of $C$. elegans: Wnts are in control. Curr. Opin. Genet. Dev. 17: 320-325. Abstract Article

Slack, F. and G. Ruvkun, 1997 Temporal pattern formation by heterochronic genes. Annu. Rev. Genet. 31: 611-634. Abstract Article

Sommer, R.J., 2005 Evolution of development in nematodes related to C. elegans (December 14, 2005), WormBook, ed. The C. elegans Research Community, WormBook, doi/10.1895/wormbook.1.46.1, http://www.wormbook.org. Abstract Article

Sönnichsen B., L. B. Koski, A. Walsh, P. Marschall, B. Neumann et al., 2005 Full-genome RNAi profiling of early embryogenesis in Caenorhabditis elegans. Nature 434: 462-469. Abstract Article

Spieth, J. and D. Lawson, 2006 Overview of gene structure (January 18, 2006), WormBook, ed. The C. elegans Research Community, WormBook, doi/10.1895/wormbook.1.65.1, http://www.wormbook.org. Abstract Article

Starich, T., M. Sheehan, J. Jadrich, J. Shaw, 2001 Innexins in C. elegans. Cell Commun. Adhes. 8: 311-314. Abstract Article 
Sternberg, P.W., 2005 Vulval development (June, 25 2005), WormBook, ed. The C. elegans Research Community, WormBook, doi/10.1895/wormbook.1.6.1, http://www.wormbook.org. Abstract Article

Stout, R. F. Jr, and V. Parpura, 2012 Cell culturing of Caenorhabditis elegans glial cells for the assessment of cytosolic $\mathrm{Ca}^{2+}$ dynamics. Methods Mol. Biol. 814: 153-174. Abstract Article

Sulston, J., M. Dew, and S. Brenner, 1975 Dopaminergic neurons in the nematode Caenorhabditis elegans. J. Comp. Neurol. 163: 215-226. Abstract Article

Sulston, J. and J. Hodgkin, 1988. Methods, The nematode C. elegans, edited by W.B. Wood. Cold Spring Harbor Laboratory Press, Cold Spring Harbor, NY.

Sulston, J. E. and H.R. Horvitz, 1977 Post-embryonic cell lineages of the nematode, Caenorhabditis elegans. Dev. Biol. 56: 110-156. Abstract Article

Sulston, J. E., Albertson D. G., and J. N. Thomson, 1980 The Caenorhabditis elegans male: postembryonic development of nongonadal structures. Dev. Biol. 78: 542-576. Abstract Article

Sulston, J. E., E. Schierenberg, J. G. White, and J. N. Thomson, 1983 The embryonic cell lineage of the nematode Caenorhabditis elegans. Dev. Biol. 100: 64-119. Abstract Article

Sundaram, M. V., 2013 Canonical RTK-Ras-ERK signaling and related alternative pathways. (July 11, 2013) WormBook, ed. The C. elegans Research Community, WormBook, doi: 10.1895/wormbook.1.80.2. http://www.wormbook.org. Abstract Article

Swan, K. A., D. E. Curtis, K. B. McKusick, A. V. Voinov, F. A. Mapa et al., 2002 High-throughput gene mapping in Caenorhabditis elegans. Genome Res. 12: 1100-1105. Abstract

Tabara, H., A. Grishok, and C. C. Mello. 1998 RNAi in C. elegans: soaking in the genome sequence. Science 282: 430-431. Abstract Article

Thompson, O., M. Edgley, P. Strasbourger, S. Flibotte, B. Ewing et al., 2013 The million mutation project: a new approach to genetics in Caenorhabditis elegans. Genome Res. 23: 1749-1762. Abstract Article

Timmons, L., and A. Fire, 1998 Specific interference by ingested dsRNA. Nature 395: 854. Abstract Article

Troemel, E. R., J. H. Chou, N.D. Dwyer, H.A. Colbert, and C. I. Bargmann, 1995 Divergent seven transmembrane receptors are candidate chemosensory receptors in C. elegans. Cell 83: 207-218. Abstract Article

Vella, M.C. and F. J. Slack, 2005 C. elegans microRNAs (September 21, 2005), WormBook, ed. The C. elegans Research Community, WormBook, doi/10.1895/wormbook.1.26.1, http://www.wormbook.org. Abstract Article

Waaijers, S. and M. Boxem, 2014 Engineering the Caenorhabditis elegans genome with CRISPR/Cas9. Methods 68: 381-388. Abstract Article

Wang, L., C. R. Eckmann, L. C. Kadyk, M. Wickens, and J Kimble, 2002 A regulatory cytoplasmic poly(A) polymerase in Caenorhabditis elegans. Nature 419: 312-316. Abstract Article

Ward, S. and J. S. Carrel, 1979 Fertilization and sperm competition in the nematode Caenorhabditis elegans. Dev. Biol. 73: 304-321. Abstract Article

Ward, S., N. Thomson, J. G. White, and S. Brenner, 1975 Electron microscopical reconstruction of the anterior sensory anatomy of the nematode Caenorhabditis elegans. J. Comp. Neurol. 160: 313-337. Abstract Article

Way, J. C. and M. Chalfie, 1988 mec-3, a homeobox-containing gene that specifies differentiation of the touch receptor neurons in C. elegans. Cell 54: 5-16. Abstract Article

Wes, P. D. and C.I. Bargmann, 2001 C. elegans odour discrimination requires asymmetric diversity in olfactory neurons. Nature 410: 698-701. Abstract Article 
White, J. G., 2013 Getting into the mind of a worm-a personal view (June 25, 2013), WormBook, ed. The C. elegans Research Community, WormBook, doi/10.1895/wormbook.1.158.1, http://www.wormbook.org. Abstract Article

White, J. G., E. Southgate, J. N. Thomson, and S. Brenner, 1976 The structure of the ventral nerve cord of Caenorhabditis elegans. Philos Trans R Soc Lond. B. Biol. Sci. 275: 327-348. Abstract Article

White, J. G., E. Southgate, J. N. Thomson, and S. Brenner, 1986 The structure of the nervous system of Caenorhabditis elegans. Philos. Trans. R. Soc. Lond. B Biol. Sci. 314: 1-340. Abstract Article

Wightman, B., I. Ha, and G. Ruvkun, 1993 Posttranscriptional regulation of the heterochronic gene lin-14 by lin-4 mediates temporal pattern formation in C. elegans. Cell 75: 855-862. Abstract Article

Xu, S., T. I. Hsiao, and A. D. Chisholm, 2012 The wounded worm, using C. elegans to understand the molecular basis of skin wound healing. Worm 1: 134-138. Abstract Article

Yuan, J. and H. R. Horvitz, 1992 The Caenorhabditis elegans cell death gene ced-4 encodes a novel protein and is expressed during the period of extensive programmed cell death. Development 116: 309-320. Abstract Article

Yuan, J., S. Shaham, S. Ledoux, H. M. Ellis, and H. R. Horvitz, 1993 The C. elegans cell death gene ced-3 encodes a protein similar to mammalian interleukin-1 beta-converting enzyme. Cell 75: 641-652. Abstract Article

Zarkower, D., 2006 Somatic sex determination (February 10, 2006), WormBook, ed. The C. elegans Research Community, WormBook, doi/10.1895/wormbook.1.84.1, http://www.wormbook.org. Abstract Article

Zhang, S., D. Banerjee, and J. R. Kuhn, 2011 Isolation and culture of larval cells from C. elegans. PLoS ONE 6: e19505. Abstract Article

Zuryn, S., S. Le Gras, K. Jamet, and S. Jarriault, 2010 A strategy for direct mapping and identification of mutations by whole-genome sequencing. Genetics 186: 427-430. Abstract Article

All WormBook content, except where otherwise noted, is licensed under a Creative Commons Attribution License. 